\title{
COMPARISON OF THE POWERS OF ENERGY LOSSES IN A VARIABLE CAPACITY DISPLACEMENT PUMP DETERMINED WITHOUT OR WITH TAKING INTO ACCOUNT THE POWER OF HYDRAULIC OIL COMPRESSION
}

Zygmunt Paszota, Prof.

Gdańsk Univeristy of Technology, Poland

\begin{abstract}
Powers of energy losses in a variable capacity displacement pump are compared with or without taking into account the power of hydraulic oil compression. Evaluation of power of liquid compression in the pump was made possible by the use of method, proposed by the Author, of determining the degree of liquid aeration in the pump. In the method of determining the liquid aeration in the pump and of powers of volumetric losses of liquid compression a simplified formula $\left(q_{P v c} \times \Delta p_{P i}\right) / 2$ was used describing the field of indicated work of volumetric losses $q_{P v c}$ of liquid compression during one shaft revolution at indicated increase $\Delta p_{P i}$ of pressure in the chambers. Three methods were used for comparing the sum of powers of volumetric losses $\Delta P_{P v l}$ due to leakage and $\Delta P_{P v c}$ of compression and also $\Delta \mathrm{P}_{\mathrm{Pm}} \mid \Delta \mathrm{p}_{\mathrm{Pi}}$ of mechanical losses resulting from increase $\Delta p_{P i}$ of indicated pressure in the working chambers.
\end{abstract}

Keywords: hydrostatic drive, variable capacity displacement pump, volumetric losses of hydraulic oil compression

\section{INTRODUCTION}

In references [1-4], the Author attempted to evaluate the influence of working liquid compressibility on the picture of volumetric and mechanical losses in a high-pressure variable capacity displacement pump. The considerations were based on the assumptions made by the Author in the developed theoretical and mathematical models of torque of mechanical losses in the pump used in the hydrostatic drive [5-7]. The models assume, that increase $\Delta \mathbf{M}_{\mathbf{P m}} \mid \Delta \mathbf{p}_{\mathbf{P i}}, \mathbf{q}_{\mathbf{P g v}}$ of torque of mechanical losses in the pump „working chambers - shaft” assembly, compared with torque of losses in that assembly in a no-load pump (when indicated increase $\Delta \mathrm{p}_{\mathrm{Pi}}$ of pressure in the working chambers equals to zero $\left(\mathrm{p}_{\mathrm{Pi}}=0\right)$ is proportional to torque $\mathrm{M}_{\mathrm{Pi}}$ indicated in the pump working chambers.

In references [1-4], the Author introduced also the working

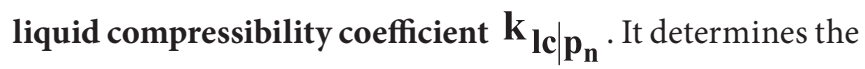

degree of decrease of the active volume of working liquid displaced by the pump during one shaft revolution as an effect of increase $\Delta \mathrm{p}_{\mathrm{Pi}}=$ pn of pressure in pump working chambers equal to the pump nominal pressure pn (pressure pn of the hydrostatic drive system where the pump operates). The pump active working volume $\mathrm{q}_{\mathrm{Pt}} \mid \mathrm{p}_{\mathrm{n}}$ or $\mathrm{q}_{\mathrm{Pgv}} \mid \mathrm{p}_{\mathrm{n}}$ is smaller compared with the active volume equal to theoretical working volume $\mathrm{q}_{\mathrm{Pt}}$ or geometrical working volume $\mathrm{q}_{\mathrm{Pgv}}$ (determined at the increase $\Delta \mathrm{p}_{\mathrm{P}_{\mathrm{i}}}$ of pressure equal to zero $-\Delta \mathrm{p}_{\mathrm{P}_{\mathrm{i}}}=0$ ). Decreases then the indicated torque $\mathrm{M}_{\mathrm{Pi}}$ and indicated power $\mathrm{P}_{\mathrm{Pi}_{\mathrm{i}}}$ in the pump working chambers which can be generated (and calculated) with the increase $\Delta \mathrm{p}_{\mathrm{Pi}}$ of pressure in the chambers, for example with $\Delta \mathrm{p}_{\mathrm{Pi}}=\mathrm{p}_{\mathrm{n}}$. In effect, decreases also torque $\mathrm{M}_{\mathrm{P}}$ on the pump drive shaft and power $\mathrm{P}_{\mathrm{P}_{\mathrm{c}}}$ consumed by the pump on shaft that the pump driving motor can be loaded with.

In references $[1-4]$ the Author searched for value of the 
liquid compressibility coefficient $\mathrm{k}_{1 \mathrm{c} \mid \mathrm{p}_{\mathrm{n}}}$, which, with increase $\Delta \mathrm{p}_{\mathrm{Pi}}$ of pressure in the working chambers equal to nominal pressure $\mathrm{p}_{\mathrm{n}}$, will give the increase $\Delta \mathrm{M}_{\mathrm{Pm}} \mid \mathrm{p}_{\mathrm{n}}, \mathrm{q}_{\mathrm{Pgv}}$ of torque of mechanical losses proportional to $\mathrm{q}_{\mathrm{Pgv}}$, i.e to indicated

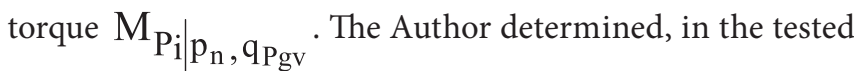
pump HYDROMATIK A7V.58.1.R.P.F.00 [8], an approximate value of oil compressibility coefficient during the pump test as $\left.\mathrm{k}_{\mathrm{lc}}\right|_{32 \mathrm{MPa}}=0,030$. Such value of the compressibility coefficient resulted also from aeration $(\varepsilon>0)$ of oil in conduits of the test stand.

In references $[10,11]$ the Author presents the method of determining the value of liquid aeration coefficient $\varepsilon$ during pump operation in a hydrostatic drive system or on a test stand, consisting in finding such value of $\varepsilon$, with which calculated increase $\Delta \mathrm{M}_{\mathrm{Pm}} \mid \mathrm{p}_{\mathrm{n}}, \mathrm{q}_{\mathrm{Pgv}}$ of torque of mechanical losses is proportional to indicated torque $M_{\mathrm{Pi}} \mid \mathrm{p}_{\mathrm{n}}, \mathrm{q}_{\mathrm{Pgv}}$ determined (calculated) at constant increase $\left(\mathrm{p}_{\mathrm{Pi}}=\mathrm{cte}\right)$ of pressure in the pump working chambers. The constant value of $\Delta \mathrm{p}_{\mathrm{Pi}}$, assumed in searching for liquid aeration coefficient $\varepsilon$, equals to pump nominal pressure pn $\left(\Delta \mathrm{p}_{\mathrm{Pi}_{\mathrm{i}}}=\mathrm{cte}=\mathrm{p}_{\mathrm{n}}\right)$.

Increase $\Delta \mathrm{M}_{\mathrm{Pm}} \mid \mathrm{p}_{\mathrm{n}}, \mathrm{q}_{\mathrm{Pgv}}$ of torque of mechanical losses in the pump „working chambers - shaft” assembly, at a constant value of $\Delta \mathrm{p}_{\mathrm{Pi}}\left(\Delta \mathrm{p}_{\mathrm{Pi}}=\right.$ cte), is (in Author's opinion) proportional to the pump geometrical working capacity $\mathrm{q}_{\mathrm{pgv}}$, therefore:

only with taking into account the actual value of aeration coefficient $\varepsilon$ of liquid displaced by the pump, the (calculated) relation

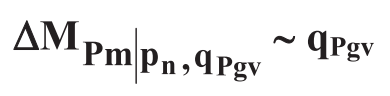

\section{can be obtained.}

At the same time, only with accounting for actual value of liquid aeration coefficient $\varepsilon$ the calculated increase $\Delta \mathrm{M}_{\mathrm{Pm} \mid \mathrm{p}_{\mathrm{n}} ; \mathrm{q}_{\mathrm{Pgv}} ; \varepsilon}$ of torque of mechanical losses tends to zero at the geometrical working capacity $\mathrm{q}_{\mathrm{Pgv}}$ per one shaft revolution tending to zero:

$$
\Delta \mathrm{M}_{\mathrm{Pm} \mid \mathrm{p}_{\mathrm{n}} ; \mathrm{q}_{\mathrm{Pgv}} \rightarrow 0 ; \varepsilon} \rightarrow 0 \text { when } \mathrm{q}_{\mathrm{Pgv}} \rightarrow 0
$$

The calculated aeration coefficient $\varepsilon$ of oil used during tests of HYDROMATIK A7V.58.1.R.P.F.00 pump, corresponding to the situation described by the expressions (1) and (2) had the value $\varepsilon=0,0135[8,10,11]$.

The method, proposed by the Author, of determining (calculating) the working liquid aeration coefficient $\varepsilon$ was for the first time used in the research work carried out by Jan Koralewski into the influence of viscosity and compressibility of aerated hydraulic oil on volumetric and mechanical losses of a HYDROMATIK A7V.58.1.R.P.F.00 pump [8, 9, 12, 13].

The method of determining (calculating) the aeration coefficient $\varepsilon$ of working liquid displaced by variable capacity per one shaft revolution displacement pump allows to subdivide the volumetric losses per one shaft revolution in pump working chambers into volumetric losses $q_{p_{v c}}$ due to compressibility of aerated (or non-aerated) liquid and volumetric losses $\mathrm{q}_{\mathrm{Pvl}}$ due to leakage in the pump.

The method allows also to evaluate the increase $\Delta \mathbf{M}_{\mathbf{P m}} \Delta_{\mathbf{p}_{\mathbf{P i}}}, \mathbf{q}_{\mathbf{P g v}}$ of torque of mechanical losses in the pump „working chambers - shaft” assembly being a function of torque $\mathbf{M}_{\mathbf{P i}} \mid \Delta \mathbf{p}_{\mathbf{P i}}, \mathbf{q}_{\mathbf{P g v}}$ indicated in the pump working chambers (by making possible more precise calculation of indicated torque $\mathrm{M}_{\mathrm{Pi}}$ ).

In Author's opinion, the above mentioned possibilities have not existed so far. They are important for evaluation of volumetric losses due to leakage of liquid in the working chambers and for evaluation of mechanical losses in the pump „working chambers - shaft” assembly, i.e. are important for evaluation of a design solution of a displacement pump generating those losses, particularly operating in the conditions of high increase $\Delta \mathrm{p}_{\mathrm{Pi}}$ of pressure in the working chambers.

Aim of the work [14,15] was to develop a capability of evaluating the volumetric losses resulting from hydraulic oil compression in the pump working chambers as a function of the same parameters, which volumetric losses due to leakage, resulting from the quality of design solution of the pump, are evaluated as dependent on and also as a function of the oil aeration coefficient $\varepsilon$. Therefore, it was necessary to develop a mathematical model describing the hydraulic oil compressibility coefficient $\mathrm{k}_{\mathrm{lc}} \mid \Delta \mathrm{p}_{\mathrm{Pi}} ; \mathrm{b}_{\mathrm{P}} ; \varepsilon ; \mathrm{v}$ as a relation to the ratio $\Delta \mathrm{p}_{\mathrm{pi}_{\mathrm{i}}} / \mathrm{pn}$ of indicated increase $\Delta \mathrm{p}_{\mathrm{p}_{\mathrm{i}}}$ of pressure in the working chambers to the nominal pressure $\mathrm{pn}$, to the pump capacity coefficient $b_{\mathrm{p}}$, to the oil aeration coefficient $\varepsilon$ and to the ratio $v / v_{n}$ of oil viscosity $v$ to reference viscosity $v_{\mathrm{n}}$. Also presented was a mathematical model of volumetric losses $\mathrm{q}_{\mathrm{Pvc}} \Delta \mathrm{p}_{\mathrm{Pi}} ; \mathrm{b}_{\mathrm{P}} ; \varepsilon ; \mathrm{v}$ of hydraulic oil compression in the pump working chambers in the form allowing to use it in the model of power of compression in the pump and also in the model of losses and pump energy efficiency.

It has to be noted, that, in order to simplify calculations of indicated torque $\mathrm{M}_{\mathrm{Pi}}$ in the pump working chambers, the calculations taking into account the liquid compression in the chambers, the liquid compression curve was replaced by linear approximation as the change of volume is small. This simplification gives a slight error at small values of liquid aeration coefficient $\varepsilon$, but the error increases at greater values of $\varepsilon$. The evaluation of error due to the simplification can be made by comparing the sum of power of volumetric and mechanical losses in pump resulting from indicated increase 
$\Delta \mathrm{p}_{\mathrm{p}_{\mathrm{i}}}$ of pressure in the working chambers determined without or with taking into account the power of liquid compression. However, the balance of powers of losses determined without or with taking into account the power of liquid compression in the working chambers is mainly a tool of demonstrating the errors in evaluation of energy losses in pump resulting from not taking into account of the influence of liquid compression power.

\section{DIAGRAM OF POWER INCREASE IN A DISPLACEMENT PUMP OPPOSITE TO DIRECTION OF POWER FLOW ACCOUNTING FOR POWER OF VOLUMETRIC LOSSES OF LIQUID COMPRESSION}

The proposed method of determining the value of aeration coefficient $\varepsilon$ of working liquid displaced by a variable capacity displacement pump per one shaft revolution allows to estimate the subdivision of volumetric losses in the pump working chambers into volumetric losses $\mathrm{q}_{\mathrm{Pvc}}$ of compression and volumetric losses $\mathrm{q}_{\mathrm{Pvl}_{\mathrm{v}}}$ due to leakage in the chambers. The method allows also to evaluate the increase $\Delta \mathrm{M}_{\mathrm{Pm}} \mid \Delta \mathrm{p}_{\mathrm{Pi}}$ of torque of mechanical losses in the pump „working chambers - shaft" assembly.

Volumetric losses $\mathrm{q}_{\mathrm{p}_{\mathrm{vc}}}$ of liquid compression, $\mathrm{q}_{\mathrm{pvl}}$ of leakage and increase $\Delta \mathrm{M}_{\mathrm{Pm} \mid \Delta \mathrm{p}_{\mathrm{Pi}}}$ of torque of mechanical losses are losses of different character and at the same time different functions of increase $\Delta \mathrm{p}_{\mathrm{Pi}}$ of pressure in the working chambers.

Figure 1 presents and describes the diagram of increase of power in a displacement pump opposite to the direction of power flow eliminating the Sankey diagram of decrease of power in the direction of power flow which causes erroneous evaluation of losses in pump energy investigations. The proposed diagram accounts for the subdivision of power of volumetric losses in the pump working chambers into power of losses of liquid compression and power of losses due to leakage.

The diagram presents relation of power $\mathrm{P}_{\mathrm{Pc}_{\mathrm{c}}}$ consumed by pump (power required by the pump from its driving (electric, internal combustion) motor) as a sum of pump useful power $\mathrm{P}_{\mathrm{P}_{\mathrm{u}}}$ required of the pump by working liquid displaced by it (required of the pump by the hydrostatic system driven by it), power $\Delta \mathrm{P}_{\mathrm{Pp}}$ of pressure losses in the channels, power $\Delta \mathrm{P}_{\mathrm{Pv}}$ of volumetric leakage in the working chambers, power $\Delta \mathrm{P}_{\mathrm{Pvc}}$ of liquid compression in the working chambers and power
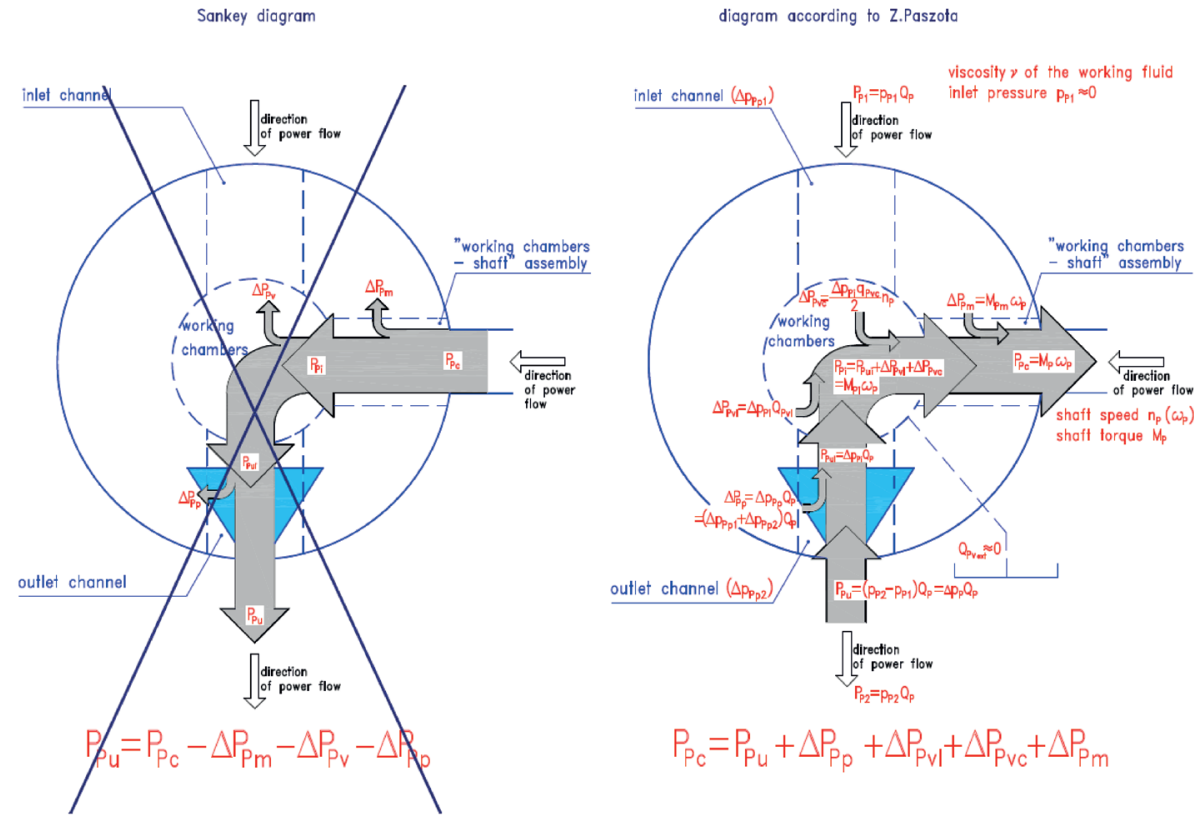

Fig.1 Diagram of power increase in a displacement pump opposite to the direction of power flow, eliminating the Sankey diagram of power decrease in the direction of power flow

Power increases from pump useful power $P_{P_{u}}$ required of pump by the pressed working liquid (required of pump by the driven hydrostatic system), to consumed power $P_{p_{c}}$ required by pump on its shaft from its driving (electric, internal combustion) motor.

Increase of power in the pump is an effect of powers of energy losses in it, resulting from quality of the displacement pump design solution generating those losses, and power of volumetric losses due to compression of the working liquid. Powers of losses in the pump resulting from quality of its structural solution are the following: power $\Delta P_{P_{p}}$ of pressure losses in the channels, power $\Delta P$ of volumetric losses due to leakage in working chambers and power $\Delta P_{P_{n}}$ of mechanical losses in the „working chambers shaft" assembly.

Powers $\Delta P_{P p}, \Delta P_{P v l}$ and $\Delta P_{P m}$ of losses in the pump are functions of output parameters of the pump assembly, where the losses occur and diversified functions of liquid viscosity $v$ :

- power $\Delta P_{p_{p}}$ of pressure losses in the channels is a function of pump capacity $Q_{p}$ and of liquid viscosity $v$,

- power $\Delta P_{P V l}$ of volumetric losses due to leakage in the working chambers is a function of increase $\Delta p_{P_{i}}$ of pressure indicated in the chambers and of liquid viscosity $v$,

- power $\Delta \mathrm{P}_{P_{m}}$ of mechanical losses in the "working chambers - shaft” assembly is a sum $\Delta \mathrm{P}_{\mathrm{Pm}}=\Delta \mathrm{P}_{\mathrm{Pm}}\left|\Delta \mathrm{p}_{\mathrm{Pi}}=0+\Delta \mathrm{P}_{\mathrm{Pm}}\right| \Delta \mathrm{p}_{\mathrm{Pi}}$ of power $\Delta \mathrm{P}_{\mathrm{Pm}} \mid \Delta \mathrm{p}_{\mathrm{Pi}}=0$ of losses resulting from torque $\mathrm{M}_{\mathrm{Pm}} \Delta \mathrm{p}_{\mathrm{Pi}}=0$ of losses in a no-load pump (at $\Delta p_{P_{i}}=0$ ) and power $\Delta \mathrm{P}_{\mathrm{Pm}} \mid \Delta \mathrm{p}_{\mathrm{Pi}}$ of losses resulting from increase $\Delta \mathrm{M}_{\mathrm{Pm}} \mid \Delta \mathrm{p}_{\mathrm{Pi}}$ of torque of losses proportional to torque $M_{P i}$ indicated in the working chambers. Torque $\mathrm{M}_{\mathrm{Pm}} \mid \Delta \mathrm{p}_{\mathrm{Pi}}=0$ of losses in a no-load pump depends on the liquid viscosity $v$

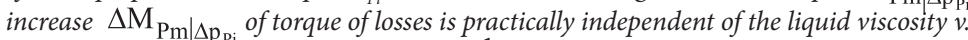

The greater is the liquid compressibility coefficient $\mathrm{k}_{\mathrm{lc}} \mathrm{p}_{\mathrm{n}}$ and the greater is the increase $\Delta p_{P_{i}}$ of pressure indicated in the working chambers, the greater is power $\Delta P_{p_{v c}}$ of volumetric losses of liquid compression.

Useful power $P_{P u i}$ in the working chambers: $P_{P u i}=P_{P_{u}}+\Delta P_{P p}$

Power $P_{P_{i}}$ indicated in the working chambers: $P_{P_{i}}=P_{P_{u i}}+\Delta P_{P_{v l}}+\Delta P_{P_{v c}}=P_{P_{u}}+\Delta P_{p_{p}}+\Delta P_{P_{v l}}+\Delta P_{p_{v c}}$

Power $P_{P_{c}}$ consumed by pump on the shaft: $P_{P_{c}}=P_{P i}+\Delta P_{P m}=P_{P u}+\Delta P_{P p}+\Delta P_{P v l}+\Delta P_{P v c}+\Delta P_{P_{m}}$

The proposed diagram eliminates the Sankey diagram of distribution of power in the pump causing erroneous evaluation of losses in the pump energy investigations. 
$\Delta \mathrm{P}_{\mathrm{Pm}}$ of mechanical losses in the pump „working chambers shaft" assembly. Power $\Delta \mathrm{P}_{\mathrm{Pm}}$ of mechanical losses is a sum $\Delta \mathrm{P}_{\mathrm{Pm}}=\Delta \mathrm{P}_{\mathrm{Pm} \mid \Delta \mathrm{p}_{\mathrm{Pi}}=0}+\Delta \mathrm{P}_{\mathrm{Pm} \mid \Delta \mathrm{p}_{\mathrm{Pi}} \quad \text { of power }}$ $\Delta \mathrm{P}_{\mathrm{Pm} \mid \Delta \mathrm{p}_{\mathrm{Pi}}=0}$ of losses resulting from torque $\mathrm{M}_{\mathrm{Pm} \mid \Delta \mathrm{p}_{\mathrm{Pi}}=0}$ of losses in no-load pump (at $\Delta \mathrm{p}_{\mathrm{Pi}_{\mathrm{i}}}=0$ ) and power $\Delta \mathrm{P}_{\mathrm{Pm}} \mid \Delta \mathrm{p}_{\mathrm{Pi}}$ of losses resulting from increase $\Delta \mathrm{M}_{\mathrm{Pm} \mid \Delta \mathrm{p}_{\mathrm{Pi}}}$ of torque of losses proportional to torque $\mathrm{M}_{\mathrm{Pi}}$ indicated in the working chambers.

Diagram of the increase of power in the pump may be described by the equation:

$\mathrm{P}_{\mathrm{Pc}}=\mathrm{P}_{\mathrm{Pu}}+\Delta \mathrm{P}_{\mathrm{Pp}}+\Delta \mathrm{P}_{\mathrm{Pvl}}+\Delta \mathrm{P}_{\mathrm{Pvc}}+\Delta \mathrm{P}_{\mathrm{Pm} \mid \Delta \mathrm{p}_{\mathrm{Pi}}=0}+\Delta \mathrm{P}_{\mathrm{Pm}} \mid \Delta \mathrm{p}_{\mathrm{Pi}}$

Power $\Delta \mathrm{P}_{\mathrm{Pp}}$ of pressure losses in the pump channels and power $\Delta \mathrm{P}_{\mathrm{Pm} \mid \Delta \mathrm{p}_{\mathrm{Pi}}=0}$ of mechanical losses in the pump „working chambers - shaft” assembly (resulting from torque $\mathrm{M}_{\mathrm{Pm} \mid \Delta \mathrm{p}_{\mathrm{Pi}}=0}$ of losses in no-load pump (at $\left.\Delta \mathrm{p}_{\mathrm{Pi}}=0\right)$ ) are independent of the increase $\Delta \mathrm{p}_{\mathrm{Pi}}$ of pressure in the working chambers.

Power $\Delta \mathrm{P}_{\mathrm{Pvl}}$ of volumetric losses due to leakage and power $\Delta \mathrm{P}_{\mathrm{Pvc}}$ of volumetric losses of liquid compression in the pump working chambers and also power $\Delta \mathrm{P}_{\mathrm{Pm}} \mid \Delta \mathrm{p}_{\mathrm{Pi}}$ of mechanical losses in the pump „working chambers - shaft” assembly

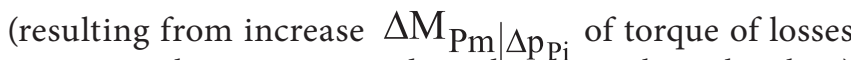
proportional to torque $\mathrm{M}_{\mathrm{Pi}}$ indicated in the working chambers) are dependent on increase $\Delta \mathrm{p}_{\mathrm{Pi}}$ of pressure in the chambers.

In the investigations of energy losses in pump we can easily determine the pump useful power $\mathrm{P}_{\mathrm{Pu}}=\mathrm{Q}_{\mathrm{P}} \Delta \mathrm{p}_{\mathrm{P}}$, power $\Delta \mathrm{P}_{\mathrm{Pp}}=\mathrm{Q}_{\mathrm{P}} \Delta \mathrm{p}_{\mathrm{P}_{\mathrm{p}}}$ of pressure losses in the channels, power $\Delta \mathrm{P}_{\mathrm{Pm} \mid \Delta \mathrm{p}_{\mathrm{Pi}}=0}=\omega_{\mathrm{P}} \Delta \mathrm{M}_{\mathrm{Pm} \mid \Delta \mathrm{p}_{\mathrm{Pi}}=0}$ of mechanical losses in the no-load pump $\left(\Delta \mathrm{p}_{\mathrm{Pi}}=0\right)$,working chambers - shaft" assembly and power $\mathrm{P}_{\mathrm{P}_{\mathrm{c}}}=\omega_{\mathrm{P}} \mathrm{M}_{\mathrm{P}}$ consumed by the pump on the shaft.

The sum of power of volumetric losses $\Delta \mathrm{P}_{\mathrm{Pvl}}$ due to leakage and $\Delta \mathrm{PPvc}$ of liquid compression and also power $\Delta \mathrm{P}_{\mathrm{Pm}} \mid \Delta \mathrm{p}_{\mathrm{Pi}}$ of mechanical losses (resulting from increase $\Delta \mathrm{M}_{\mathrm{Pm}} \mid \Delta \mathrm{p}_{\mathrm{Pi}}$ of torque of mechanical losses) results from the equation:

$\Delta \mathrm{P}_{\mathrm{Pvl}}+\Delta \mathrm{P}_{\mathrm{Pvc}}+\Delta \mathrm{P}_{\mathrm{Pm} \mid \Delta \mathrm{p}_{\mathrm{Pi}}}=\mathrm{P}_{\mathrm{Pc}_{\mathrm{c}}}-\mathrm{P}_{\mathrm{Pu}}-\Delta \mathrm{P}_{\mathrm{Pp}}-\Delta \mathrm{P}_{\mathrm{Pm}} \mid \Delta \mathrm{p}_{\mathrm{Pi}_{\mathrm{i}}=0}$

The method of determining the aeration coefficient $\varepsilon$ of liquid pressed by a variable capacity displacement pump makes it possible to subdivide the volumetric losses into losses $\mathrm{q}_{\mathrm{pvc}}$ of liquid compression and losses $\mathrm{q}_{\mathrm{pvl}}$ due to leakage and also to evaluate more precisely the increase $\Delta \mathrm{M}_{\mathrm{Pm}} \mid \Delta \mathrm{p}_{\mathrm{Pi}}$ of torque of mechanical losses. In effect, it makes it possible to evaluate powers $\Delta \mathrm{P}_{\mathrm{Pvl}}, \Delta \mathrm{P}_{\mathrm{Pvc}}$ and $\Delta \mathrm{P}_{\mathrm{Pm}} \mid \Delta \mathrm{p}_{\mathrm{Pi}}$ of three losses dependent on increase $\Delta \mathrm{p}_{\mathrm{Pi}}$ of pressure in the pump working chambers.

\section{INFLUENCE OF VOLUMETRIC LOSSES QPVC PER ONE SHAFT REVOLUTION DUE TO HYDRAULIC OIL COMPRESSION IN THE PUMP WORKING CHAMBERS ON EVALUATION OF VOLUMETRIC LOSSES QPVL DUE TO LEAKAGE OF OIL IN THE CHAMBERS AND ON EVALUATION OF TORQUE MPM OF MECHANICAL LOSSES IN THE PUMP „WORKING CHAMBERS - SHAFT" ASSEMBLY}

Volumetric losses $\mathrm{q}_{\mathrm{Pvc}}$, determined per one shaft revolution, of compression of liquid pressed in the pump working chambers are not attributable to the pump design solution. They result from the liquid compressibility itself and from aeration of the liquid. Main reason of working liquid aeration is air dissolved in the liquid (not having in such form any influence on its compressibility) and getting out of the liquid (in the form of bubbles) in the conditions of local (in the system conduits or in pump working chambers during their connection with pump inlet channel) drop of pressure below the atmospheric pressure. One of the reasons may be admitting by the hydrostatic system designer or user too low pressure in the pump inlet conduit, which may cause cavitation in the pump working chambers during their connection with the inlet channel.

Mathematical model of volumetric losses $\mathrm{q}_{\mathrm{Pvc}} \mid \Delta \mathrm{p}_{\mathrm{Pi}} ; \mathrm{b}_{\mathrm{P}} ; \varepsilon ; v$ per one shaft revolution resulting from compression of nonaerated $(\varepsilon=0)$ or aerated $(\varepsilon>0)$ hydraulic oil, determined at indicated increase $\Delta \mathrm{p}_{\mathrm{Pi}}$ of pressure in the pump working chambers, at pump capacity coefficient $b_{\mathrm{p}}$ (in the $0<\mathrm{b}_{\mathrm{p}} \leq 1$ range) and at the ratio $v / v$ n of oil viscosity $v$ to reference viscosity $\nu_{\mathrm{n}}$ is described (with $\Delta \mathrm{p}_{\mathrm{Pi}}>3,2 \mathrm{MPa}$ ) by the formula:

$$
\begin{aligned}
& \mathrm{q}_{\mathrm{Pvc} \mid \Delta \mathrm{p}_{\mathrm{Pi}} ; \mathrm{b}_{\mathrm{P}} ; \varepsilon ; \mathrm{v}}=\mathrm{k}_{1 \mathrm{c} \mid \Delta \mathrm{p}_{\mathrm{Pi}} ; \mathrm{b}_{\mathrm{P}} ; \varepsilon ; v} \mathrm{q}_{\mathrm{Pgv}}= \\
& =\mathrm{k}_{\mathrm{lc} \mid \Delta \mathrm{p}_{\mathrm{Pi}} ; \mathrm{b}_{\mathrm{P}} ; \varepsilon ; v} \mathrm{~b}_{\mathrm{P}} \mathrm{q}_{\mathrm{Pt}}= \\
& =\frac{1+\mathrm{b}_{\mathrm{P}}}{2 \mathrm{~b}_{\mathrm{P}}}\left[\mathrm{k}_{\mathrm{lc} \mid \mathrm{p}_{\mathrm{n}} ; \varepsilon=0}\left(\Delta \mathrm{p}_{\mathrm{Pi}} / \mathrm{p}_{\mathrm{n}}\right)^{\mathrm{a} p \mathrm{p}}+\varepsilon\right]\left(\mathrm{v} / \mathrm{v}_{\mathrm{n}}\right)^{\mathrm{a}_{\mathrm{vc}}} \mathrm{b}_{\mathrm{P}} \mathrm{q}_{\mathrm{Pt}}=
\end{aligned}
$$

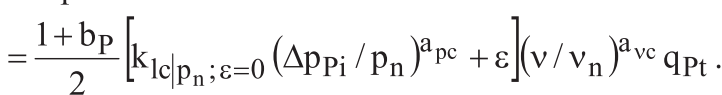

with exponent $\mathrm{a}_{\mathrm{pc}}=0,89$

and with exponent $\mathrm{a}_{v \mathrm{c}}=-0,12$.

Coefficient $\mathrm{k}_{\mathrm{lc}} \mid \mathrm{p}_{\mathrm{n}} ; \varepsilon=0$ of hydraulic oil compressibility is a coefficient of non-aerated oil compressibility. At nominal pressure $\mathrm{p}_{\mathrm{n}}=32 \mathrm{MP}$, this coefficient is of an order $\mathrm{k}_{\mathrm{lc} 32 \mathrm{MPa} ; \varepsilon=0}=0,020$.

With a given value $\mathrm{q}_{\mathrm{P}} \mathrm{p}_{\mathrm{n}}$ of pump capacity per one shaft revolution, required of pump at nominal pressure $\left(\Delta \mathrm{p}_{\mathrm{Pi}}=\right.$ $p_{n}$ ) by the hydrostatic system fed by it, and simultaneously with the increasing value $\mathrm{q}_{\mathrm{P}_{\mathrm{vc}}}$ of capacity losses per one shaft revolution due to liquid compressibility in the sum $\mathrm{q}_{\mathrm{Pv}_{\mathrm{v}}}=\mathrm{q}_{\mathrm{Pvl}}+\mathrm{q}_{\mathrm{Pvc}_{\mathrm{vc}}}$ of volumetric losses per one shaft revolution, 
decreases the value $M_{p_{i}}$ of indicated torque in the working chambers and value $M_{P}$ of torque on the pump shaft. Not taking into account of losses $q_{p_{v c}}$ in calculations of torque $M_{p i}$ and treating $\mathrm{q}_{\mathrm{Pvc}_{\mathrm{vc}}}$, in the sum $\mathrm{q}_{\mathrm{Pv}_{\mathrm{v}}}=\mathrm{q}_{\mathrm{Pvl}_{\mathrm{vl}}}+\mathrm{q}_{\mathrm{Pvc}}$ as $\mathrm{q}_{\mathrm{Pvl}}$, results in increasing the calculated torque $\mathrm{M}_{\mathrm{Pi}}$ and decreasing the calculated torque $\mathrm{M}_{\mathrm{Pm}}=\mathrm{M}_{\mathrm{p}}-\mathrm{M}_{\mathrm{Pi}}$ of losses in the pump "working chambers - shaft" assembly. This is an effect of the fact, that volumetric losses $\mathrm{q}_{\mathrm{pvl}}$ per one shaft revolution (due to leakage) have approximately twice as big effect on the value of calculated torque $M_{\mathrm{pi}_{i}}$ indicated in the working chambers as the effect of the same value of volumetric losses $\mathrm{q}_{\mathrm{p}_{\mathrm{vc}}}$ per one shaft revolution (due to liquid compression).

Figure 2 presents and describes the subdivision of intensity $\mathrm{q}_{\mathrm{Pv}}=\mathrm{q}_{\mathrm{pvl}}+\mathrm{q}_{\mathrm{pvc}}$ of volumetric losses per one shaft revolution in the pump working chambers, the losses dependent on indicated increase $\Delta \mathrm{p}_{\mathrm{Pi}}$ of pressure in the chambers, into intensity $\mathrm{q}_{\mathrm{Pvl}} \mid \Delta \mathrm{p}_{\mathrm{Pi}}$ of volumetric losses per one shaft revolution due to working liquid (hydraulic oil) leakage and into intensity $\mathrm{q}_{\mathrm{Pvc}} \mid \Delta \mathrm{p}_{\mathrm{Pi}}$ of volumetric losses per one shaft revolution due to liquid compression, the subdivision made at pump capacity coefficient $\mathrm{b}_{\mathrm{P}}=1$.

The figure presents also the values $\mathrm{q}_{\mathrm{Pt}} \mathrm{p}_{\mathrm{n}}$ of working liquid active volume displaced by the pump during one shaft revolution at $\Delta \mathrm{p}_{\mathrm{Pi}}=\mathrm{pn}$, the volume determined with the assumption of non-compressible liquid (liquid compressibility coefficient $\mathrm{k}_{\mathrm{lc} \mid \mathrm{p}_{\mathrm{n}}}=0$ ) or with the assumption of compressible liquid with liquid aeration coefficient $\varepsilon=0$ or $\varepsilon>0$, and also the values $\mathrm{q}_{\mathrm{pt}}$ of theoretical working volume displaced at $\Delta \mathrm{p}_{\mathrm{Pi}}=0$, determined with assumption of $\mathrm{k}_{1 \mathrm{c}} \mathrm{p}_{\mathrm{n}}=0$ or with assumption of $\varepsilon=0$ or $\varepsilon>0$, the values $\mathrm{q}_{\mathrm{pt}}$ being the liquid active volume displaced by the pump at $\Delta \mathrm{p}_{\mathrm{Pi}}=0$.

Values $\mathrm{q}_{\mathrm{Pt}} \mathrm{p}_{\mathrm{n}} ; \varepsilon=0$ or $\mathrm{q}_{\mathrm{Pt}}\left|\mathrm{p}_{\mathrm{n}} ; \varepsilon\right\rangle 0$ result from a sum of the value $\mathrm{q}_{\mathrm{P}} \mid \mathrm{p}_{\mathrm{n}}$ of pump capacity per one shaft revolution, required of the pump by the driven hydrostatic system at $\Delta \mathrm{p}_{\mathrm{Pi}}=\mathrm{p}_{\mathrm{n}}$, and, with the assumption of compressible liquid, from intensity $\mathrm{q}_{\mathrm{Pvl}} \mid \mathrm{p}_{\mathrm{n}}$ of volumetric losses per one shaft revolution due to leakage in the working chambers at $\Delta \mathrm{p}_{\mathrm{Pi}_{\mathrm{i}}}=$ $\mathrm{p}_{\mathrm{n}}$ (leakage independent of liquid aeration, i.e. the same at $\varepsilon=0$ and $\varepsilon>0$ ). With the assumption of non-compressible

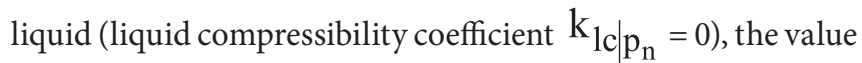
$\mathrm{q}_{\mathrm{Pt}} \mid \mathrm{p}_{\mathrm{n}} ; \mathrm{k}_{\mathrm{lc} \mid \mathrm{p}_{\mathrm{n}}=0}$ (equal to the value $\mathrm{q}_{\mathrm{Pt}} \mid \mathrm{k}_{\mathrm{lc} \mid \mathrm{p}_{\mathrm{n}}}=0$ ) results from a sum of value $q_{P v l} \mid p_{n}$ of pump capacity per one shaft revolution (required of the pump by the hydrostatic system), intensity $\mathrm{q}_{\mathrm{Pvl}} \mid \mathrm{p}_{\mathrm{n}}$ of losses due to leakage and intensity $\mathrm{q}_{\mathrm{Pvc}} \mid \mathrm{p}_{\mathrm{n}} ; \varepsilon=0$ of losses due to compression of non-aerated liquid $(\varepsilon=0)$.

The sum $\mathrm{q}_{\mathrm{P} \mid \mathrm{p}_{\mathrm{n}}}+\mathrm{q}_{\mathrm{P}_{\mathrm{vl}} \mid \mathrm{p}_{\mathrm{n}}}+\mathrm{q}_{\mathrm{P}_{\mathrm{vc}}} \mid \mathrm{p}_{\mathrm{n}}$ of the pump capacity $\mathrm{q}_{\mathrm{P}} \mid \mathrm{p}_{\mathrm{n}}$ per one shaft revolution (required of the pump by the driven hydrostatic system at $\Delta \mathrm{p}_{\mathrm{Pi}_{\mathrm{i}}}=\mathrm{p}_{\mathrm{n}}$ ), the intensity $\mathrm{q}_{\mathrm{P}_{\mathrm{vl}}} \mid \mathrm{p}_{\mathrm{n}}$ of volumetric losses per one shaft revolution due to leakage in working chambers at $\Delta \mathrm{p}_{\mathrm{Pi}_{\mathrm{i}}}=\mathrm{p}_{\mathrm{n}}$ and the intensity $\mathrm{q}_{\mathrm{P}_{\mathrm{vc}}} \mid \mathrm{p}_{\mathrm{n}}$ of volumetric losses per one shaft revolution due to compressibility of non-aerated $(\varepsilon=0)$ or aerated $(\varepsilon>0)$ liquid in the working chambers at $\Delta \mathrm{p}_{\mathrm{Pi}}=$ pn decides of theoretical working volume $\mathrm{q}_{\mathrm{pt}}$ per one shaft revolution, i.e. of the active volume displaced by the pump at $\Delta \mathrm{p}_{\mathrm{Pi}}=0$ :

$$
\mathrm{q}_{\mathrm{Pt}}=\mathrm{q}_{\mathrm{P} \mid \mathrm{p}_{\mathrm{n}}}+\mathrm{q}_{\mathrm{P}_{\mathrm{vl}} \mid \mathrm{p}_{\mathrm{n}}}+\mathrm{q}_{\mathrm{P}_{\mathrm{vc}}} \mathrm{p}_{\mathrm{n}}
$$

The value $\mathrm{q}_{\mathrm{Pt}} \mid \mathrm{k}_{\mathrm{lc} \mid \mathrm{p}_{\mathrm{n}}=0}$ of theoretical working volume per one shaft revolution, determined with the assumption of noncompressible liquid (liquid compressibility coefficient $\mathrm{k}_{1 \mathrm{c}} \mathrm{p}_{\mathrm{n}}=$ 0 ) and the value $\left.\mathrm{q}_{\mathrm{Pt}}\right|_{\varepsilon=0}$ of theoretical working volume per one shaft revolution, determined with the assumption of nonaerated liquid $\left(\varepsilon=0\right.$ ), result from a sum $\mathrm{q}_{\mathrm{Pt}} \mathrm{p}_{\mathrm{n}} ; \varepsilon=0$ (equal to $\left.\mathrm{q}_{\mathrm{Pt}} \mid \mathrm{p}_{\mathrm{n}} ; \varepsilon>0\right)$ and intensity $\mathrm{q}_{\mathrm{Pvc}} \mid \mathrm{p}_{\mathrm{n}} ; \varepsilon=0$ of losses due to compression of non-aerated liquid.

The value $\left.\mathrm{q}_{\mathrm{Pt}}\right|_{\varepsilon>0}$ of theoretical working volume per one shaft revolution, determined with the assumption of aerated liquid $\left(\varepsilon>0\right.$ ), results from a sum of $\mathrm{q}_{\mathrm{Pt}} \mid \mathrm{p}_{\mathrm{n}} ; \varepsilon>0$ (equal to $\left.\mathrm{q}_{\mathrm{Pt}} \mid \mathrm{p}_{\mathrm{n}} ; \varepsilon=0\right)$ and intensity $\mathrm{q}_{\mathrm{Pvc}} \mid \mathrm{p}_{\mathrm{n}} ; \varepsilon>0$ of losses due to compression of aerated liquid.

Figure 3 presents and describes the field of indicated work in the displacement pump working chambers during one shaft revolution. The work performed in working chambers decides of the value of torque $\mathrm{M}_{\mathrm{Pi}}$ indicated in the chambers.

Torque $\mathrm{M}_{\mathrm{Pi}}$ indicated in the chambers is a result of three works:

- work described as a product of capacity $\mathrm{q}_{\mathrm{P}} \mid \mathrm{p}_{\mathrm{n}}$ per one shaft revolution and indicated increase $\Delta \mathrm{p}_{\mathrm{P}_{\mathrm{i}}}=\mathrm{p}_{\mathrm{n}}$ of pressure $-\mathrm{q}_{\mathrm{P}} \mathrm{p}_{\mathrm{n}} \times \mathrm{p}_{\mathrm{n}}$,

- $\quad$ work described as a product of volumetric losses $\mathrm{q}_{\mathrm{Pvl}}$ due to leakage and indicated increase $\Delta \mathrm{p}_{\mathrm{P}_{\mathrm{i}}}=\mathrm{p}_{\mathrm{n}}$ of pressure - $\mathrm{q}_{\mathrm{Pvl}} \mid \mathrm{p}_{\mathrm{n}} \times \mathrm{p}_{\mathrm{n}}$,

- work described, in approximation, as half of the product of volumetric losses $\mathrm{q}_{\mathrm{Pvc}} \mathrm{p}_{\mathrm{n}}$ of liquid compression and indicated increase $\Delta \mathrm{p}_{\mathrm{Pi}}=\mathrm{p}_{\mathrm{n}}$ of pressure $-\left(\mathrm{q}_{\mathrm{Pvc}} \mid \mathrm{p}_{\mathrm{n}}\right.$ $\left.\times \mathrm{p}_{\mathrm{n}}\right) / 2$.

Simplified formula describing indicated torque $\mathrm{M}_{\mathrm{Pi}}$ has the form:

$\mathrm{M}_{\mathrm{Pi} \mid \Delta \mathrm{p}_{\mathrm{Pi}}=\mathrm{p}_{\mathrm{n}} ; \mathrm{b}_{\mathrm{P}}=1}=\left(\mathrm{q}_{\mathrm{P} \mid \mathrm{p}_{\mathrm{n}}}+\mathrm{q}_{\mathrm{P}_{\mathrm{vl}} \mid \mathrm{p}_{\mathrm{n}}}+\frac{\mathrm{q}_{\mathrm{P}_{\mathrm{vc}} \mid \mathrm{p}_{\mathrm{n}}}}{2}\right) \frac{\mathrm{p}_{\mathrm{n}}}{2 \Pi}$.

Not taking the liquid compressibility into account, i.e. 


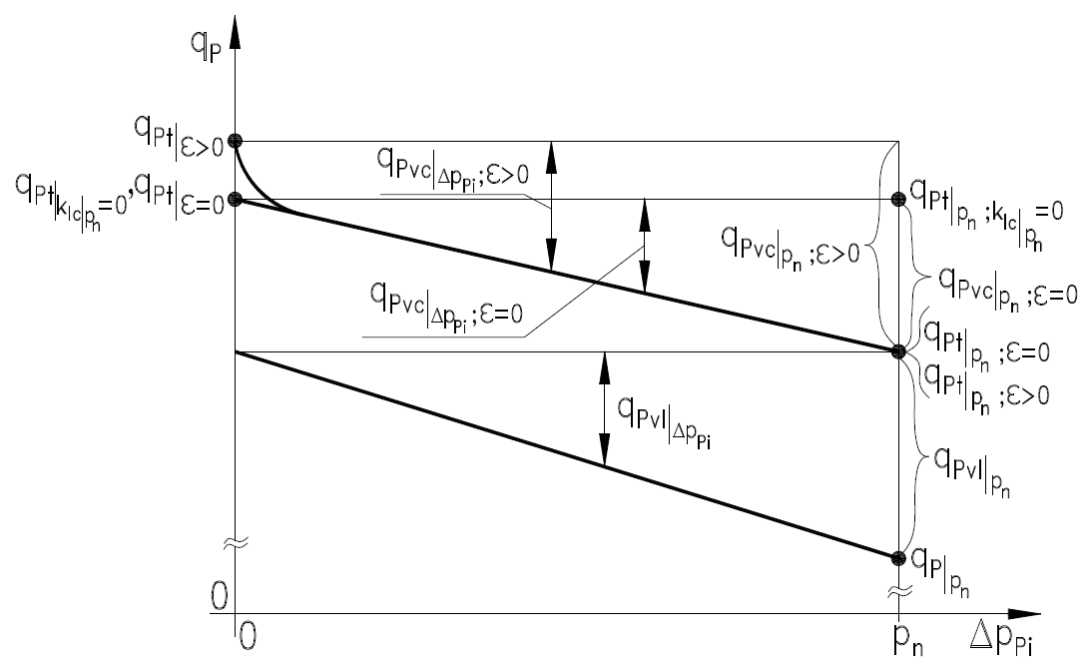

Fig.2 Subdivision of intensity of volumetric losses $q_{P_{v}}=q_{P v l}+$ $q_{P v c}$ per one shaft revolution in the pump working chambers, the losses dependent on indicated increase $\Delta p_{p_{i}}$ of pressure

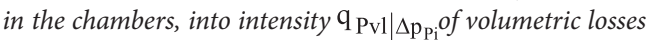
due to leakage (independent of liquid aeration coefficient ع) and intensity $\mathrm{q}_{\mathrm{Pvc} \mid \Delta \mathrm{p}_{\mathrm{Pi}}}$ of volumetric losses due to liquid compressibility, the subdivision made at pump capacity coefficient $b_{p}=1$ :

$\mathrm{q}_{\mathrm{P}} \mid \mathrm{p}_{\mathrm{n}}$ - pump capacity per one shaft revolution required of the pump by the hydrostatic system driven by it at $\Delta p_{p_{i}}=p_{n^{2}}$

$\mathrm{q}_{\mathrm{Pt}} \mid \mathrm{p}_{\mathrm{n}}$ - required values of active working volume of working liquid displaced by the pump at $\Delta p_{p i}=p_{n}$, determined with the assumption of $\mathrm{k}_{1 \mathrm{c} \mid \mathrm{p}_{\mathrm{n}}}=0$ or with the assumption of $\varepsilon=0$ or $\varepsilon>0$,

$q_{p_{t}}-$ required values of theoretical working capacity per one shaft revolution, i.e. active volume of liquid displaced by the pump at $\Delta p_{P_{i}}=0$, determined with the assumption of $\mathrm{k}_{1 \mathrm{c} \mid \mathrm{p}_{\mathrm{n}}}=0$ or with assumption of $\varepsilon=$ 0 or $\varepsilon>0$.

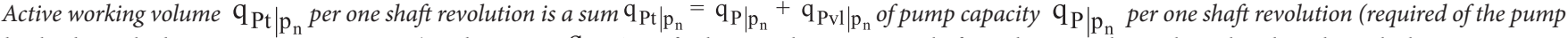
by the driven hydrostatic system at $\Delta p_{P_{i}}=p_{n}$ ) and intensity $\mathrm{q}_{\mathrm{Pvl}} \mathrm{p}_{\mathrm{n}}$ of volumetric losses per one shaft revolution in the working chambers due to leakage at $\Delta p_{P_{i}}=p_{n}$; with the assumption of non-compressible liquid, i.e. $\mathrm{k}_{\mathrm{lc} \mid \mathrm{p}_{\mathrm{n}}}=0$, the active volume $\mathrm{q}_{\mathrm{Pt}} \mid \mathrm{p}_{\mathrm{n}} ; \mathrm{k}_{\mathrm{lc} \mid \mathrm{p}_{\mathrm{n}}=0}$ (equal to volume $\mathrm{q}_{\mathrm{Pt}} \mid \mathrm{k}_{\mathrm{lc} \mid \mathrm{p}_{\mathrm{n}}}=0$ ) is also increased by intensity $\mathrm{q}_{\mathrm{Pvc}} \mid \mathrm{p}_{\mathrm{n}} ; \varepsilon=0$ of volumetric losses per one shaft revolution due to compression of non-aerated $(\varepsilon=0)$ liquid.

Theoretical working capacity $q_{P_{t}}$ per one shaft revolution, i.e. active volume of liquid displaced by the pump at $\Delta p_{P_{i}}=0$, is a sum $q_{P t}=q_{P_{t}}=q_{P t} p_{n}+q_{P v c} p_{n}$ of active working volume $\mathrm{q}_{\mathrm{Pt}} \mid \mathrm{p}_{\mathrm{n}}$ per one shaft revolution at $\Delta p_{P_{i}}=p_{n}$ and of volumetric losses $\mathrm{q}_{\mathrm{Pvc}} \mid \mathrm{p}_{\mathrm{n}}$ per one shaft revolution due to compression of non-aerated

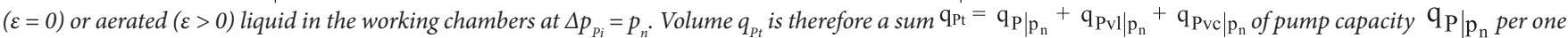
shaft revolution (required of the pump by the driven hydrostatic system at $\Delta p_{P_{i}}=p_{n}$ ), intensity $\mathrm{q}_{\mathrm{Pvl}} \mathrm{p}_{\mathrm{n}}$ of volumetric losses per one shaft revolution due to leakage in the working chambers at $\Delta p_{P_{i}}=p_{n}$ and volumetric losses $\mathrm{q}_{\mathrm{Pvc}} \mathrm{p}_{\mathrm{n}}$ per one shaft revolution due to compression of non-aerated $(\varepsilon=0)$ or aerated ( $\varepsilon>0$ ) liquid in the working chambers at $\Delta p_{p_{i}}=p_{n}$

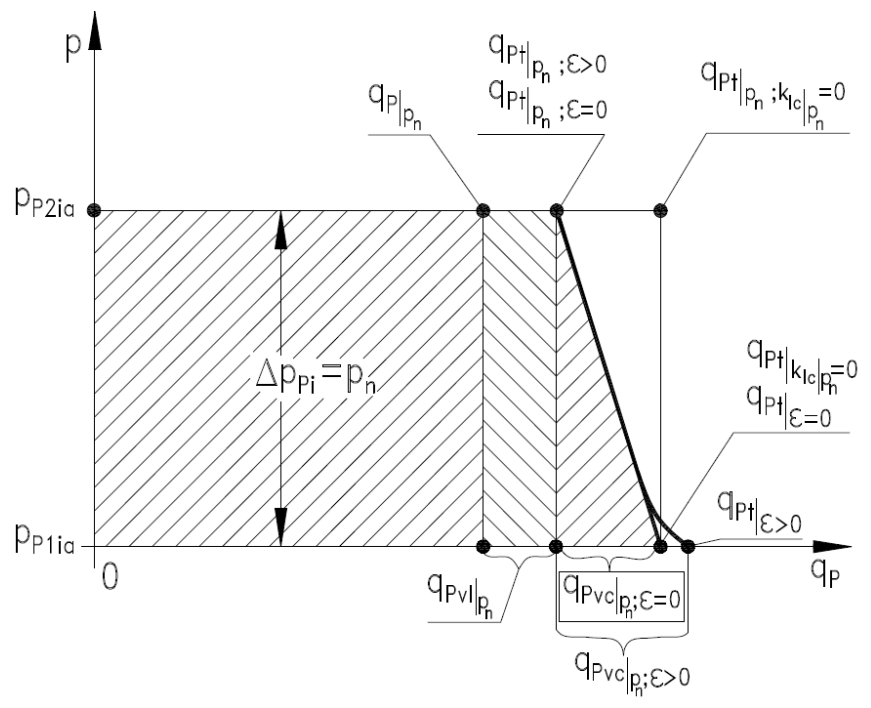

Fig.3 Area of indicated work field in the working chambers of displacement pump during one pump shaft revolution, deciding of the value $M_{p_{i}}$ of torque indicated in the chambers at indicated increase $\Delta p_{P_{i}}$ of pressure in the chambers equal to pump nominal pressure $p_{n}-\Delta p_{p_{i}}=p_{n}$, determined at the pump capacity coefficient $b_{p}=1$ :

$\mathrm{q}_{\mathrm{P}} \mid \mathrm{p}_{\mathrm{p}}$ - pump capacity per one shaft revolution (required of the pump by the pump fed hydrostatic system) at $\Delta p_{P_{i}}=p_{n^{\prime}}$

$\mathrm{q}_{\mathrm{Pt}} \mathrm{p}$ - required values of active volume of liquid displaced by the pump per one shaft revolution at $\Delta p_{P_{i}}=p_{n^{2}}$ determined with the assumption of $\mathrm{k}_{1 \mathrm{c} \mid \mathrm{p}_{\mathrm{n}}}=0$ or the assumption of $\varepsilon=0$ or $\varepsilon>0$,

$q_{P t}$ - required values of theoretical working volume per one shaft revolution, i.e. active volume of liquid displaced by the pump at $\Delta p_{p_{0}}=0$, determined with the assumption of $\mathrm{k}_{\mathrm{lc} \mid \mathrm{p}_{\mathrm{n}}}=0$ or the assumption of
$\varepsilon=0$ or $>0$,

$\mathrm{q}_{\mathrm{Pvl}} \mid \mathrm{p}_{\mathrm{n}}$ - intensity of volumetric losses per one shaft revolution due to leakage in the working chambers at $\Delta p_{P_{i}}=p_{n}$

$\mathrm{q}_{\mathrm{Pvc}} \mid \mathrm{p}_{\mathrm{n}}-$ volumetric losses per one shaft revolution, calculated at $\Delta p_{p_{i}}=p_{n^{\prime}}$, due to liquid compressibility with the assumption of $\varepsilon=0$ or $\varepsilon>0$,

$\mathrm{q}_{\mathrm{P}} \mid \mathrm{p}_{\mathrm{n}} \mathrm{p}_{\mathrm{n}}$ - a fragment of field of indicated work in the working chambers, a product of capacity $\mathrm{q}_{\mathrm{P}} \mid \mathrm{p}_{\mathrm{n}}$ per one shaft revolution (required of the pump by the fed hydrostatic system at $p_{P_{i}}=p_{n}$ ) and increase $\Delta p_{P_{i}}=p_{n}$ of pressure in the chambers,

$\mathrm{q}_{\mathrm{Pvl} \mid \mathrm{p}_{\mathrm{n}}} \mathrm{p}_{\mathrm{n}}$ - a fragment of field of indicated work in the working chambers, a product of intensity $\mathrm{q}_{\mathrm{Pvl}} \mid \mathrm{p}_{\mathrm{n}}$ of volumetric losses due to leakage in the chambers (during displacement of the liquid by the pump at $\Delta p_{P_{i}}=p_{n}$ ) and increase $\Delta p_{P_{i}}=p_{n}$ in the chambers,

$\left(\mathrm{q}_{\mathrm{Pvc}} \mid \mathrm{p}_{\mathrm{n}} \mathrm{p}_{\mathrm{n}}\right) / 2-$ a fragment of field of indicated work in the working chambers, approximately constituting half of the product of volumetric losses $\mathrm{q}_{\mathrm{Pvc}} \mid \mathrm{p}_{\mathrm{n}}$ due to compressibility of liquid in the chambers at $\Delta p_{p_{i}}=p_{n}$ and increase $\Delta p_{P_{i}}=p_{n}$ of pressure in the chambers.

Compared with the value $\mathrm{q}_{\mathrm{Pt}} \mid \mathrm{p}_{\mathrm{n}}$, the theoretical working volume $q_{P t}$ is greater by a value $\mathrm{q}_{\mathrm{Pvc}} \mid \mathrm{p}_{\mathrm{n}}$ of volumetric losses due to compressibility of non-aerated ( $\varepsilon=$ 0) or aerated ( $\varepsilon>0$ ) liquid at $\Delta p_{P_{i}}=p_{n^{n}}$. Not taking into account the liquid compressibility, i.e. assuming that value $\mathrm{q}_{\mathrm{Pt}} \mid \mathrm{p}_{\mathrm{n}} ; \mathrm{k}_{\mathrm{lc} \mid \mathrm{p}_{\mathrm{n}}}=0$ is equal to value $\mathrm{q}_{\mathrm{Pt}} \mathrm{k}_{\mathrm{lc|}}=0$ , results in the calculations with unjustified increase of the field of indicated work in the chambers per one shaft revolution and, in effect, with unjustified increase of the calculated torque $M_{P i}$ in the chambers 
making the assumption that the quantity $\mathrm{q}_{\mathrm{Pt}} \mid \mathrm{p}_{\mathrm{n}} ; \mathrm{k}_{\mathrm{lc} \mid \mathrm{p}_{\mathrm{n}}}=0$ of displaced liquid is equal to theoretical working volume $\mathrm{q}_{\mathrm{Pt}} \mid \mathrm{k}_{\mathrm{lc} \mid \mathrm{p}_{\mathrm{n}}=0}$ determined at $\Delta \mathrm{p}_{\mathrm{Pi}_{\mathrm{i}}}=0$, results in calculations with unjustified increase of the field of indicated work in the working chambers during one shaft revolution and, in effect, with unjustified increase of the calculated indicated torque $\mathrm{M}_{\mathrm{Pi}_{\mathrm{i}}}$ in the chambers.

\section{TORQUE MPM OF MECHANICAL LOSSES IN A DISPLACEMENT PUMP „WORKING CHAMBERS - SHAFT" ASSEMBLY AS A FUNCTION OF INCREASE $\triangle$ PPI OF PRESSURE IN THE WORKING CHAMBERS}

In reference to papers [5 $\div$ ], figure 4 presents a picture

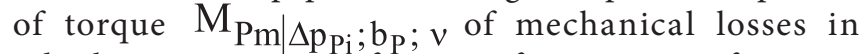
a displacement pump as a function of increase $\Delta \mathrm{p}_{\mathrm{pi}}$ of pressure in the working chambers.

The proposed mathematical models describing the torque MPm of mechanical losses in the pump, related to theoretical models of the torque of mechanical losses, take the form:

- in a pump with theoretical (constant) capacity $\mathrm{q}_{\mathrm{pt}}$ per one shaft revolution $\left(b_{\mathrm{p}}=1\right)$ :

$\mathrm{M}_{\mathrm{Pm} \mid \Delta \mathrm{p}_{\mathrm{Pi}}, v}=\mathrm{k}_{4.1} \mathrm{M}_{\mathrm{Pt}}\left(\frac{v}{v_{\mathrm{n}}}\right)^{\mathrm{a}_{\mathrm{vm}}}+\mathrm{k}_{4.2} \mathrm{M}_{\mathrm{Pt}} \frac{\Delta \mathrm{p}_{\mathrm{Pi}}}{\mathrm{p}_{\mathrm{n}}}=$

$$
\begin{aligned}
& {\left[\mathrm{k}_{4.1}\left(\frac{v}{v_{\mathrm{n}}}\right)^{\mathrm{a}_{\mathrm{vm}}}+\mathrm{k}_{4.2} \frac{\Delta \mathrm{p}_{\mathrm{Pi}}}{\mathrm{p}_{\mathrm{n}}}\right] \mathrm{M}_{\mathrm{Pt}}=} \\
= & {\left[\mathrm{k}_{4.1}\left(\frac{v}{v_{\mathrm{n}}}\right)^{\mathrm{a}_{\mathrm{vm}}}+\mathrm{k}_{4.2} \frac{\Delta \mathrm{p}_{\mathrm{Pi}}}{\mathrm{p}_{\mathrm{n}}}\right] \frac{\mathrm{q}_{\mathrm{Pt}} \mathrm{p}_{\mathrm{n}}}{2 \Pi}, }
\end{aligned}
$$

where:

$$
\mathrm{k}_{4.1}=\frac{\mathrm{M}_{\mathrm{Pm} \mid \Delta \mathrm{p}_{\mathrm{Pi}}=0, \mathrm{~b}_{\mathrm{P}}=1, v_{\mathrm{n}}}}{\mathrm{M}_{\mathrm{Pt}}}=\frac{\mathrm{M}_{\mathrm{Pm} \mid \Delta \mathrm{p}_{\mathrm{Pi}}=0, \mathrm{~b}_{\mathrm{P}}=1, v_{\mathrm{n}}}}{\frac{\mathrm{q}_{\mathrm{Pt}} \mathrm{p}_{\mathrm{n}}}{2 \Pi}},
$$

$$
\begin{array}{r}
\mathrm{k}_{4.2}=\frac{\Delta \mathrm{M}_{\mathrm{Pm} \mid \Delta \mathrm{p}_{\mathrm{Pi}}, \mathrm{b}_{\mathrm{P}}=1, v_{\mathrm{n}}}}{\mathrm{M}_{\mathrm{Pi}}}=\frac{\Delta \mathrm{M}_{\mathrm{Pm} \mid \Delta \mathrm{p}_{\mathrm{Pi}}, \mathrm{b}_{\mathrm{P}}=1, v_{\mathrm{n}}}}{\frac{\mathrm{q}_{\mathrm{Pt}} \Delta \mathrm{p}_{\mathrm{Pi}}}{2 \Pi}}= \\
=\frac{\mathrm{M}_{\mathrm{Pm} \mid \Delta \mathrm{p}_{\mathrm{Pi}}, \mathrm{b}_{\mathrm{P}}=1, v_{\mathrm{n}}}-\mathrm{M}_{\mathrm{Pm} \mid \Delta \mathrm{p}_{\mathrm{Pi}}=0, \mathrm{~b}_{\mathrm{P}}=1, v_{\mathrm{n}}}}{\frac{\mathrm{q}_{\mathrm{Pt}} \Delta \mathrm{p}_{\mathrm{Pi}}}{2 \Pi}}= \\
=\frac{\mathrm{M}_{\mathrm{Pm} \mid \Delta \mathrm{p}_{\mathrm{Pi}}=\mathrm{p}_{\mathrm{n}}, \mathrm{b}_{\mathrm{P}}=1, v_{\mathrm{n}}}-\mathrm{M}_{\mathrm{Pm} \mid \Delta \mathrm{p}_{\mathrm{Pi}}=0, \mathrm{~b}_{\mathrm{P}}=1, v_{\mathrm{n}}}}{\frac{\mathrm{q}_{\mathrm{Pt}} \mathrm{p}_{\mathrm{n}}}{2 \Pi}}= \\
=\frac{\mathrm{M}_{\mathrm{Pm} \mid \Delta \mathrm{p}_{\mathrm{Pi}}=\mathrm{p}_{\mathrm{n}}, \mathrm{b}_{\mathrm{P}}=1, v_{\mathrm{n}}}-\mathrm{M}_{\mathrm{Pm} \mid \Delta \mathrm{p}_{\mathrm{Pi}}=0, \mathrm{~b}_{\mathrm{P}}=1, v_{\mathrm{n}}}}{M_{\mathrm{Pt}}} .
\end{array}
$$

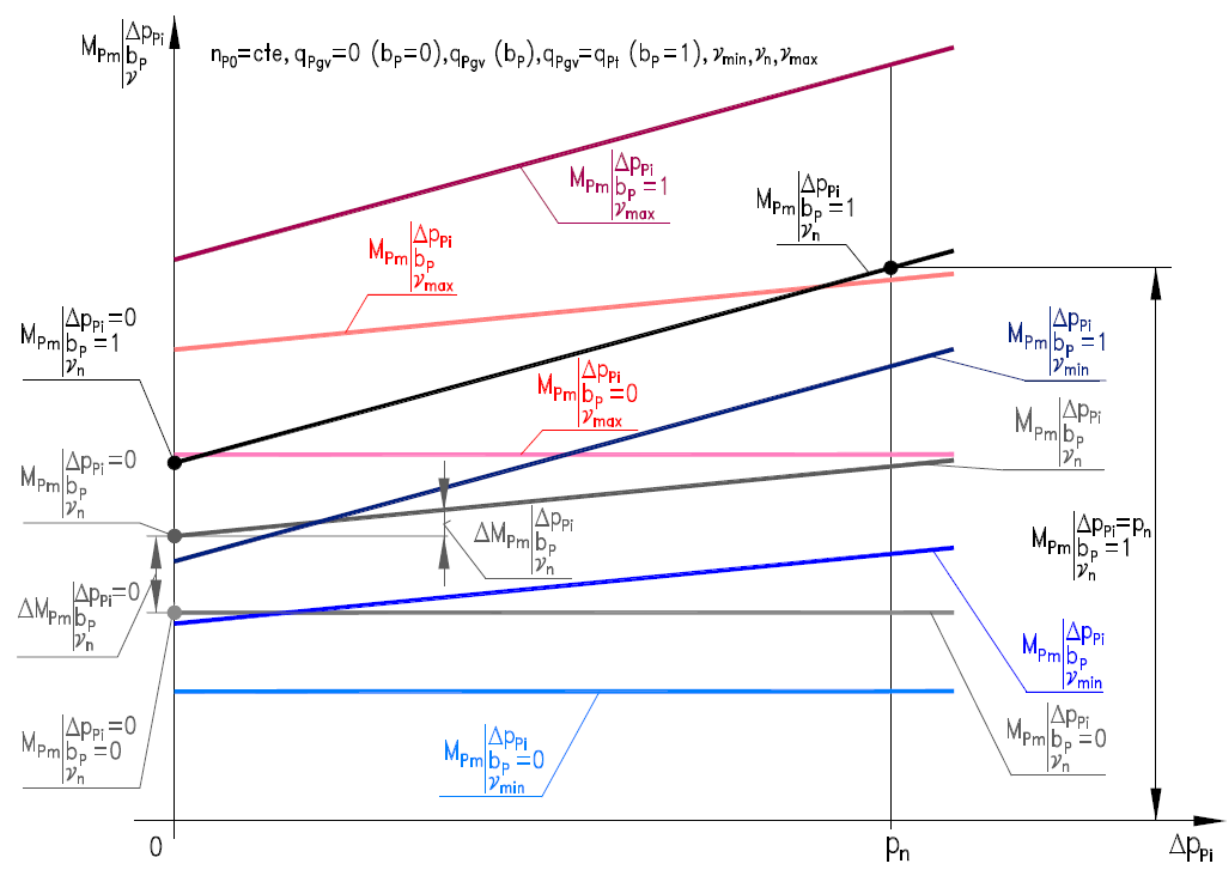

Fig.4 Torque $\mathrm{M}_{\mathrm{Pm}} \mid \Delta \mathrm{p}_{\mathrm{Pi}}, \mathrm{b}_{\mathrm{P}}, v$ of mechanical losses in a piston (axial or radial) pump with crankcase filled with liquid and with variable capacity $q_{P g v}=b_{P} q_{P t}$ per one shaft revolution, as a function of the indicated increase $\Delta p_{p_{i}}$ of pressure in the pump working chambers - graphical interpretation of theoretical model (9); capacity $q_{P g v}$ per one shaft revolution (coefficient $b_{p}$ of pump capacity): $q_{P g v}=0\left(b_{p}=0\right), q_{P g v}\left(b_{p}\right), q_{P g v}=q_{P t}\left(b_{p}=1\right.$ ); liquid viscosity $v_{\min }, v_{n}$ and $v_{\text {max }}$. Torque

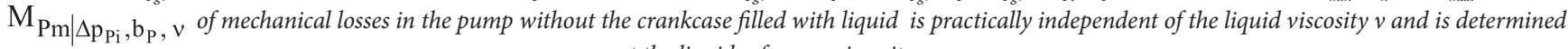
at the liquid reference viscosity $v_{n}$. 
- $\quad$ in a pump with geometrical (variable) capacity $\mathrm{q}_{\mathrm{Pgv}}$ $\left(\mathrm{q}_{\mathrm{Pgv}}=\mathrm{b}_{\mathrm{P}} \mathrm{q}_{\mathrm{Pt}}\right)$ per one shaft revolution:

$$
\begin{gathered}
\mathrm{M}_{\mathrm{Pm} \mid \Delta \mathrm{p}_{\mathrm{Pi}}, \mathrm{b}_{\mathrm{P}}, v}=\left(\mathrm{k}_{4.1 .1}+\mathrm{k}_{4.1 .2} \mathrm{~b}_{\mathrm{P}}\right) \mathrm{M}_{\mathrm{Pt}}\left(\frac{v}{v_{\mathrm{n}}}\right)^{\mathrm{a}_{\mathrm{vm}}}+\mathrm{k}_{4.2} \mathrm{M}_{\mathrm{Pt}} \mathrm{b}_{\mathrm{P}} \frac{\Delta \mathrm{p}_{\mathrm{Pi}}}{\mathrm{p}_{\mathrm{n}}}= \\
=\left[\left(\mathrm{k}_{4.1 .1}+\mathrm{k}_{4.1 .2} \mathrm{~b}_{\mathrm{P}}\right)\left(\frac{v}{v_{\mathrm{n}}}\right)^{\mathrm{a}_{\mathrm{vm}}}+\mathrm{k}_{4.2} \mathrm{~b}_{\mathrm{P}} \frac{\Delta \mathrm{p}_{\mathrm{Pi}}}{\mathrm{p}_{\mathrm{n}}}\right] \mathrm{M}_{\mathrm{Pt}}= \\
=\left[\left(\mathrm{k}_{4.1 .1}+\mathrm{k}_{4.1 .2} \mathrm{~b}_{\mathrm{P}}\right)\left(\frac{\mathrm{v}}{v_{\mathrm{n}}}\right)^{\mathrm{a}_{\mathrm{vm}}}+\mathrm{k}_{4.2} \mathrm{~b}_{\mathrm{P}} \frac{\Delta \mathrm{p}_{\mathrm{Pi}}}{\mathrm{p}_{\mathrm{n}}}\right] \frac{\mathrm{q}_{\mathrm{Pt}} \mathrm{p}_{\mathrm{n}}}{2 \Pi},
\end{gathered}
$$

where:

$$
\begin{gathered}
\mathrm{k}_{4.1 .1}=\frac{\mathrm{M}_{\mathrm{Pm} \mid \Delta \mathrm{p}_{\mathrm{Pi}}=0, \mathrm{~b}_{\mathrm{P}}=0, v_{\mathrm{n}}}}{\mathrm{M}_{\mathrm{Pt}}}=\frac{\mathrm{M}_{\mathrm{Pm} \mid \Delta \mathrm{p}_{\mathrm{Pi}}=0, \mathrm{~b}_{\mathrm{P}}=0, v_{\mathrm{n}}}}{\frac{\mathrm{q}_{\mathrm{Pt}} \mathrm{p}_{\mathrm{n}}}{2 \Pi}}, \\
\mathrm{k}_{4.1 .2}=\frac{\mathrm{M}_{\mathrm{Pm} \mid \Delta \mathrm{p}_{\mathrm{Pi}}=0, \mathrm{~b}_{\mathrm{P}}=1, v_{\mathrm{n}}}-\mathrm{M}_{\mathrm{Pm} \mid \Delta \mathrm{p}_{\mathrm{Pi}}=0, \mathrm{~b}_{\mathrm{P}}=0, v_{\mathrm{n}}}}{\mathrm{M}_{\mathrm{Pt}}}= \\
=\frac{\mathrm{M}_{\mathrm{Pm} \mid \Delta \mathrm{p}_{\mathrm{Pi}}=0, \mathrm{~b}_{\mathrm{P}}=1, v_{\mathrm{n}}}-\mathrm{M}_{\mathrm{Pm} \mid \Delta \mathrm{p}_{\mathrm{Pi}}=0, \mathrm{~b}_{\mathrm{P}}=0, v_{\mathrm{n}}}}{\frac{\mathrm{q}_{\mathrm{Pt}} \mathrm{p}_{\mathrm{n}}}{2 \Pi}},
\end{gathered}
$$$$
\mathrm{k}_{4.2}=\frac{\Delta \mathrm{M}_{\mathrm{Pm} \mid \Delta \mathrm{p}_{\mathrm{Pi}}, \mathrm{b}_{\mathrm{P}}, v_{\mathrm{n}}}}{\mathrm{M}_{\mathrm{Pi}}}=\frac{\Delta \mathrm{M}_{\mathrm{Pm} \mid \Delta \mathrm{p}_{\mathrm{Pi}}, \mathrm{b}_{\mathrm{P}}, v_{\mathrm{n}}}}{\frac{\mathrm{b}_{\mathrm{P}} \mathrm{q}_{\mathrm{Pt}} \Delta \mathrm{p}_{\mathrm{Pi}}}{2 \Pi}}=\frac{\Delta \mathrm{M}_{\mathrm{Pm}} \mid \Delta \mathrm{p}_{\mathrm{Pi}}, \mathrm{b}_{\mathrm{P}}=1, v_{\mathrm{n}}}{\frac{\mathrm{q}_{\mathrm{Pt}} \Delta \mathrm{p}_{\mathrm{Pi}}}{2 \Pi}}=
$$$$
=\frac{\mathrm{M}_{\mathrm{Pm} \mid \Delta \mathrm{p}_{\mathrm{Pi}}=\mathrm{p}_{\mathrm{n}}, \mathrm{b}_{\mathrm{P}}=1, v_{\mathrm{n}}}-\mathrm{M}_{\mathrm{Pm} \mid \Delta \mathrm{p}_{\mathrm{Pi}}=0, \mathrm{~b}_{\mathrm{P}}=1, v_{\mathrm{n}}}}{\frac{\mathrm{q}_{\mathrm{Pt}} \mathrm{p}_{\mathrm{n}}}{2 \Pi}}=
$$$$
=\frac{\mathrm{M}_{\mathrm{Pm} \mid \Delta \mathrm{p}_{\mathrm{Pi}}=\mathrm{p}_{\mathrm{n}}, \mathrm{b}_{\mathrm{P}}=1, v_{\mathrm{n}}}-\mathrm{M}_{\mathrm{Pm} \mid \Delta \mathrm{p}_{\mathrm{Pi}}=0, \mathrm{~b}_{\mathrm{P}}=1, v_{\mathrm{n}}}}{\mathrm{M}_{\mathrm{Pt}}} \text {. }
$$

\section{COMPARISON OF THE POWERS OF THE ENERGY LOSSES IN A DISPLACEMENT PUMP DETERMINED WITHOUT OR WITH TAKING INTO ACCOUNT OF POWER OF HYDRAULIC OIL COMPRESSION - INVESTIGATIONS OF A HYDROMATIK A7V.58.1.R.P.F.00 PUMP $[8 \div 15]$}

Let us determine a sum of power of volumetric and mechanical losses resulting from increase of pressure in the working chambers of a variable capacity per one shaft revolution displacement pump, at the indicated increase $\Delta \mathrm{p}_{\mathrm{P}}$ of pressure in the chambers equal to pump nominal pressure $\mathrm{pn}\left(\Delta \mathrm{p}_{\mathrm{p}_{\mathrm{i}}}=\mathrm{p}_{\mathrm{n}}\right)$, at the pump capacity coefficient $\mathrm{b}_{\mathrm{p}}=1$ and at the ratio $v / v_{\mathrm{n}}=1$ of hydraulic oil viscosity $v$ to reference viscosity $v_{n}$.

We shall use formula (4) for the purpose:

$\Delta \mathrm{P}_{\mathrm{Pvl}}+\Delta \mathrm{P}_{\mathrm{Pvc}}+\Delta \mathrm{P}_{\mathrm{Pm} \mid \Delta \mathrm{p}_{\mathrm{Pi}}}=\mathrm{P}_{\mathrm{Pc}}-\mathrm{P}_{\mathrm{Pu}}-\Delta \mathrm{P}_{\mathrm{Pp}}-\Delta \mathrm{P}_{\mathrm{Pm}} \mid \Delta \mathrm{p}_{\mathrm{Pi}}=0$, where the sum of pump useful power $\mathrm{P}_{\mathrm{Pu}}$ and power $\Delta \mathrm{P}_{\mathrm{Pp}}$ of pressure losses in the channels will be replaced by useful power $\mathrm{P}_{\mathrm{Pui}}$ in the working chambers $\left(\mathrm{P}_{\mathrm{Pui}}=\mathrm{P}_{\mathrm{Pu}}+\Delta \mathrm{P}_{\mathrm{Pp}}\right)$ (Fig.1):

$\Delta \mathrm{P}_{\mathrm{Pvl}}+\Delta \mathrm{P}_{\mathrm{Pvc}}+\Delta \mathrm{P}_{\mathrm{Pm} \mid \Delta \mathrm{p}_{\mathrm{Pi}}}=\mathrm{P}_{\mathrm{Pc}}-\mathrm{P}_{\mathrm{Pui}}-\Delta \mathrm{P}_{\mathrm{Pm} \mid \Delta \mathrm{p}_{\mathrm{Pi}}=0}$

The result obtained from formula (15) will be compared with results of investigations of volumetric and mechanical losses resulting from increase $\Delta \mathrm{p}_{\mathrm{Pi}}$ of pressure in the chambers evaluated with the proposed method of determining the degree of liquid aeration in a variable capacity displacement pump $[10,11]$ :

- without taking into account volumetric losses $\mathrm{q}_{\mathrm{P}_{\mathrm{vc}}} \mid \mathrm{p}_{\mathrm{n}}$ of oil compression, i.e. with treating $\mathrm{q}_{\mathrm{P}_{\mathrm{vc}}} \mid \mathrm{p}_{\mathrm{n}}$ as an

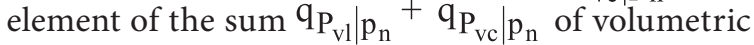
losses attributed to oil leakage in the chambers,

- with taking into account the volumetric losses $\mathrm{q}_{\mathrm{P}_{\mathrm{vc}}} \mid \mathrm{p}_{\mathrm{n}}$ of oil compression in the chambers.

The comparison will be based on results of a HYDROMATIK A7V.58.1.R.P.F.00 pump investigation [ $8 \div 15]$.

Fig. 5 presents an example of relation $\mathrm{q}_{\mathrm{p}}=\mathrm{f}\left(\Delta \mathrm{p}_{\mathrm{p}_{\mathrm{i}}}\right)$ of capacity $\mathrm{q}_{\mathrm{p}}$ per one shaft revolution to indicated increase $\Delta \mathrm{p}_{\mathrm{Pi}}$ of pressure in working chambers at pump capacity coefficient $b_{p}=1$ and at viscosity $v_{\mathrm{n}}=35 \mathrm{~mm} 2 \mathrm{~s}^{-1}$. This is an example of searching for theoretical working capacity $\mathrm{q}_{\mathrm{pt}}$ per one shaft revolution and of evaluation of subdivision of the intensity $\mathrm{q}_{\mathrm{pv}}$ of volumetric losses into volumetric losses $\mathrm{q}_{\mathrm{Pvl}}$ due to leakage of oil in the chambers and volumetric losses $\mathrm{q}_{\mathrm{pvc}}$ resulting from compression of non-aerated or aerated oil.

Fig.6 presents a picture of relations of increase

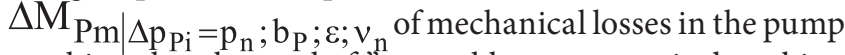
"working chambers - shaft" assembly to geometrical working capacity qPgv (to pump capacity coefficient bP) at assumed values of oil elasticity modulus $B$ and of oil aeration coefficient $\varepsilon$. The line corresponding to oil aeration coefficient $\varepsilon=0,0135$

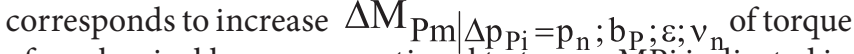
of mechanical losses proportional to torque MPi indicated in the working chambers.

The sum of powers of volumetric and mechanical losses resulting from increase $p_{\mathrm{Pi}_{\mathrm{i}}}=\mathrm{p}_{\mathrm{n}}$ of pressure in the working chambers determined by formula (15) and the sums determined in effect of direct definition of the individual powers of losses without and with taking into account the losses of oil compression in the chambers is presented below.

1. Sum $\Delta \mathbf{P}_{\mathbf{P v l} \mid \mathbf{p}_{\mathrm{n}}}+\Delta \mathbf{P}_{\mathbf{P v c} \mid \mathbf{p}_{\mathrm{n}}}+\Delta \mathbf{P}_{\mathbf{P m} \mid \mathbf{p}_{\mathbf{n}}}$ of powers of losses determined by formula (15)

Data from pump investigations:

- $\quad$ capacity $\left.\mathrm{q}_{\mathrm{P}}\right|_{\mathrm{p}_{\mathrm{n}}}=55,009 \mathrm{~cm}^{3} / \mathrm{rev}$,

- indicated increase of pressure $\Delta \mathrm{p}_{\mathrm{Pi}_{\mathrm{i}}}=\mathrm{p}_{\mathrm{n}}=32,17 \mathrm{MPa}$,

- rotational speed $\mathrm{n}_{\mathrm{P}} \mathrm{p}_{\mathrm{n}}=24,73 \mathrm{rev} / \mathrm{s}$,

- torque on shaft at $\Delta \mathrm{p}_{\mathrm{Pi}}=\mathrm{p}_{\mathrm{n}} \mathrm{M}_{\mathrm{P} \mid \mathrm{p}_{\mathrm{n}}}=308,79 \mathrm{Nm}$,

- $\quad$ torque on shaft at $\Delta \mathrm{p}_{\mathrm{Pi}}=0$

$\mathrm{M}_{\mathrm{P} \mid \Delta \mathrm{p}_{\mathrm{Pi}}=0}=\mathrm{M}_{\mathrm{Pm} \mid \Delta \mathrm{p}_{\mathrm{Pi}}=0}=6,376 \mathrm{Nm}$. 


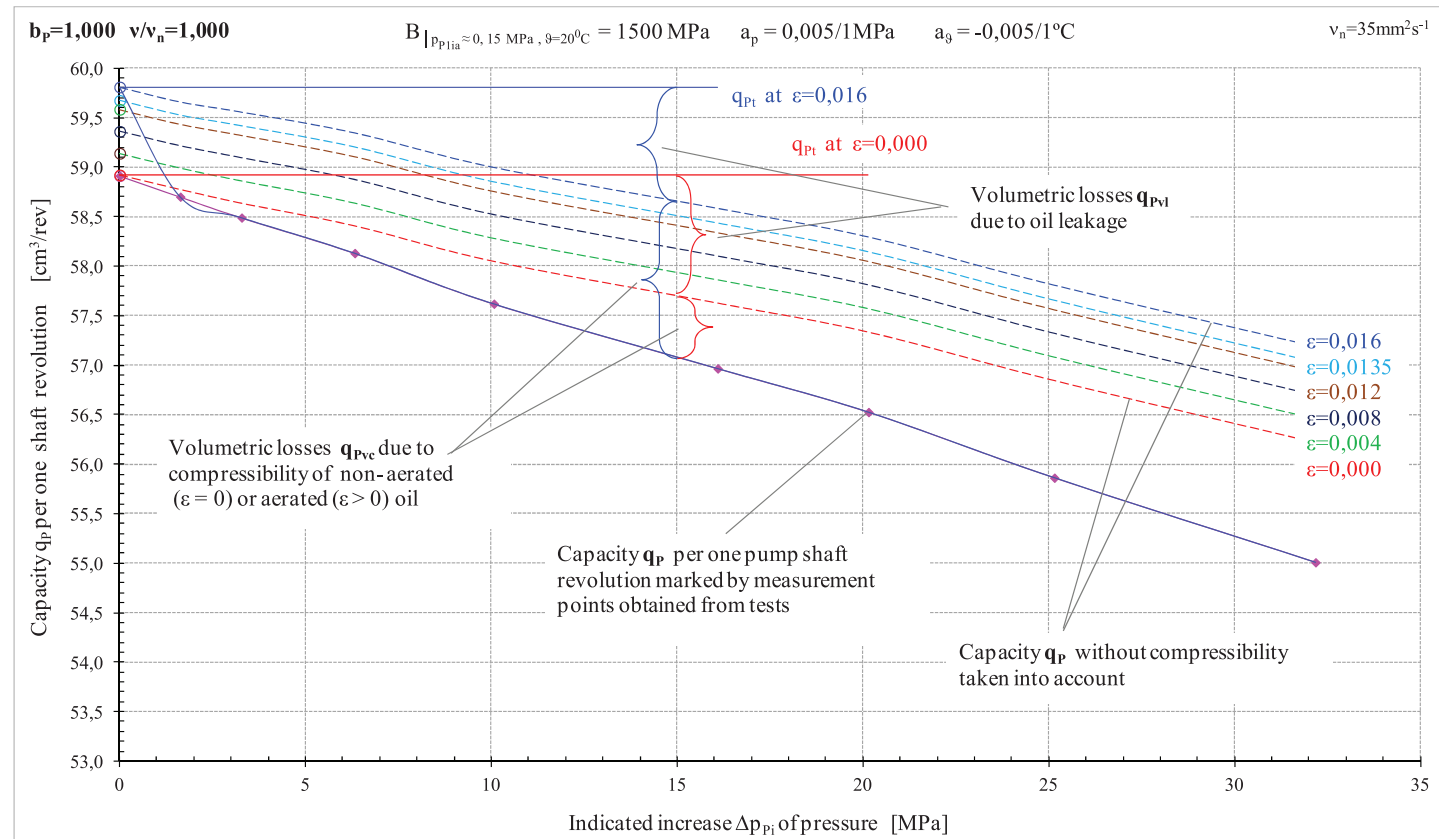

Fig. 5 Dependence of pump capacity $q_{p}$ per one shaft revolution on the indicated increase $\Delta p_{p i}$ of pressure in the working chambers, at the coefficient $b_{P}=1$ of pump capacity; the values $q_{P g v}$ of geometrical working volume and $q_{P t}$ of theoretical working volume per one shaft revolution (determined at $\Delta p_{P i}=0$ ) and subdivision of the intensity $q_{P V}=q_{P V l}+q_{P v c}$ of volumetric losses per one shaft revolution into volumetric losses $q_{P v l}$ due to oil leakage in the chambers and volumetric losses $q_{P v c}$ due to compressibility of non-aerated (or aerated) oil dependent on the value of oil aeration coefficient $\varepsilon$ ( $\varepsilon=0$ to 0,016$)$; viscosity coefficient $v / v_{n}=1$, oil temperature $\vartheta=430 \mathrm{C}$ (pump of the HYDROMATIK A7V.DR.1.R.P.F.00 type) $[8,9]$.

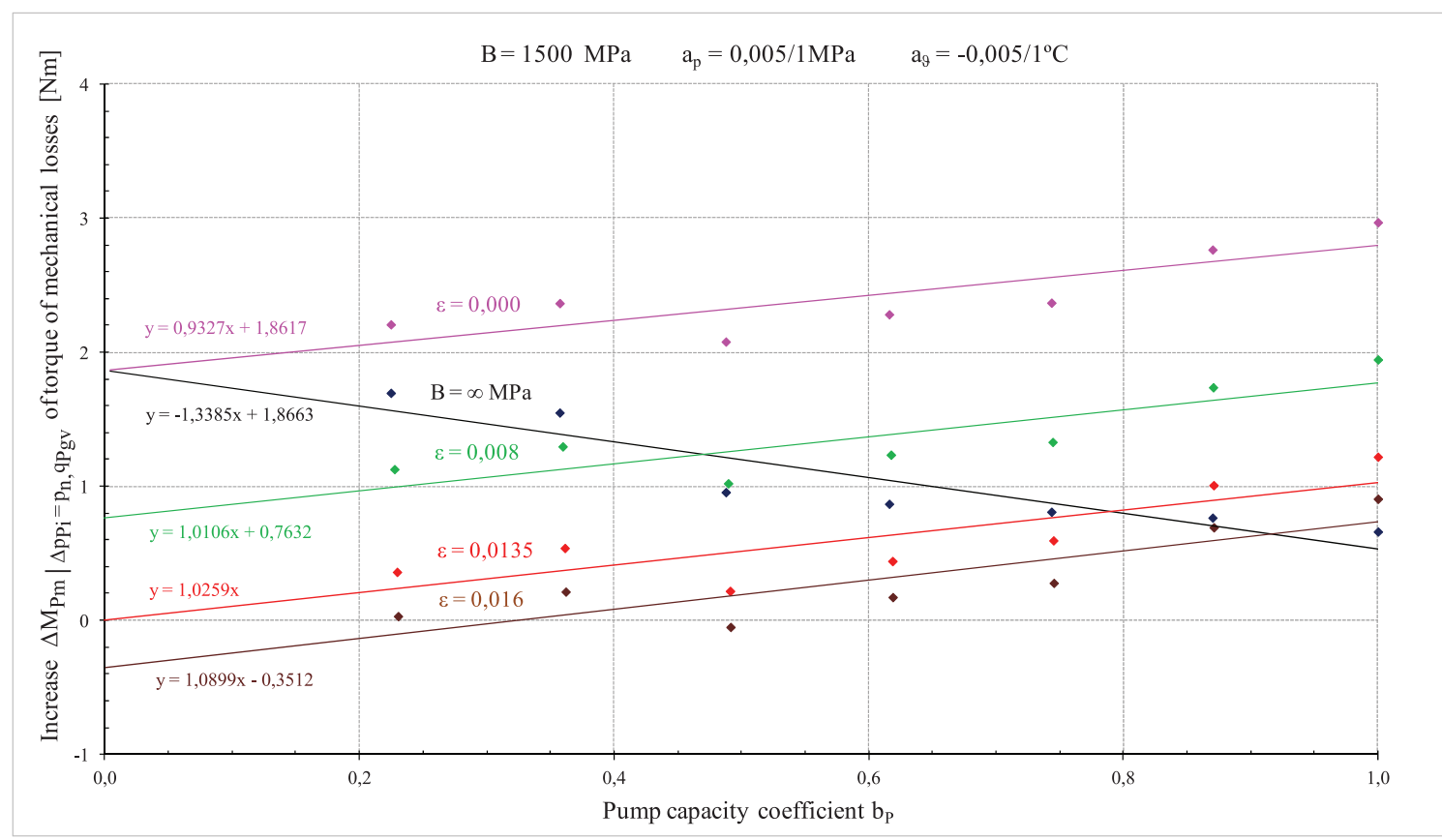

Fig. 6 Picture of the relations of increase $\Delta \mathrm{M}_{\mathrm{Pm}_{\mathrm{m}} \Delta \mathrm{P}_{\mathrm{Pi}}=32 \mathrm{MPa} ; \mathrm{q}_{\mathrm{Pg}}}$ of torque of mechanical losses in the pump „working chambers shaft" assembly (pump HYDROMATIK A7V.58.DR.1.R.P.F.00 type) to the geometrical working capacity $q_{P g v}\left(b_{p}\right.$ coefficient) with assumed values of modulus $B$ of hydraulic oil elasticity and oil aeration coefficient $\varepsilon[10,11]$ 
Useful power in pump working chambers:

$$
\mathrm{P}_{\text {Pui } \mid \mathrm{p}_{\mathrm{n}}}=\mathrm{q}_{\mathrm{P}} \times \mathrm{p}_{\mathrm{n}} \times \mathrm{n}_{\mathrm{P}}=
$$

$=55,009 \mathrm{~cm}^{3} / \mathrm{rev} \times 32,17 \mathrm{MPa} \times 24,73 \mathrm{rev} / \mathrm{s}=43763 \mathrm{~W}$

Power of mechanical losses in no-load pump:

$$
\begin{aligned}
& \Delta \mathrm{P}_{\mathrm{Pm} \mid \Delta \mathrm{p}_{\mathrm{Pi}}=0}=\mathrm{M}_{\mathrm{Pm} \mid \Delta \mathrm{p}_{\mathrm{Pi}}=0} \times 2 \Pi \mathrm{n}_{\mathrm{P}}= \\
& =6,376 \mathrm{Nm} \times 2 \Pi \times 24,73 \mathrm{rev} / \mathrm{s}=991 \mathrm{~W}
\end{aligned}
$$

Consumed power on pump shaft:

$$
\mathrm{P}_{\mathrm{Pc} \mid \mathrm{p}_{\mathrm{n}}}=\mathrm{M}_{\mathrm{P} \mid \mathrm{p}_{\mathrm{n}}} \times 2 \Pi \mathrm{n}_{\mathrm{P} \mid \mathrm{p}_{\mathrm{n}}}=
$$

$=308,73 \mathrm{Nm} \times 2 \Pi \times 24,73 \mathrm{rev} / \mathrm{s}=47972 \mathrm{~W}$

Sum of power of losses:

$\Delta \mathrm{P}_{\mathrm{Pvl} \mid p_{\mathrm{n}}}+\Delta \mathrm{P}_{\mathrm{Pvc} \mid \mathrm{p}_{\mathrm{n}}}+\Delta \mathrm{P}_{\mathrm{Pm} \mid \mathrm{p}_{\mathrm{n}}}=\mathrm{P}_{\mathrm{Pc} \mid \mathrm{p}_{\mathrm{n}}}-\mathrm{P}_{\mathrm{Pui} \mid \mathrm{p}_{\mathrm{n}}}-\Delta \mathrm{P}_{\mathrm{Pm} \mid \Delta \mathrm{p}_{\mathrm{Pi}}=0}=$

$$
=47972 \mathrm{~W}-43763 \mathrm{~W}-981 \mathrm{~W}=\mathbf{3 2 1 8} \mathrm{W}
$$

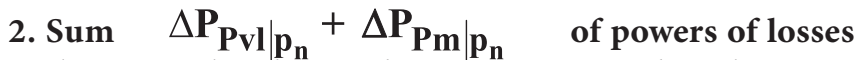
determined with not taking into account the volumetric losses of oil compression in the chambers

Data from pump investigations:

- capacity $\mathrm{q}_{\mathrm{P} \mid \mathrm{p}_{\mathrm{n}}}=55,009 \mathrm{~cm}^{3} / \mathrm{rev}$,

- theoretical capacity $\mathrm{q}_{\mathrm{pt}}=58,914 \mathrm{~cm}^{3} / \mathrm{rev}$,

- volumetric losses due to leakage

$$
\mathrm{q}_{\mathrm{Pvl} \mid \mathrm{p}_{\mathrm{n}}}=\mathrm{q}_{\mathrm{Pt}}-\mathrm{q}_{\mathrm{P} \mid \mathrm{p}_{\mathrm{n}}}=3,905 \mathrm{~cm}^{3} / \mathrm{rev} \text {, }
$$

- indicated increase of pressure $\Delta \mathrm{p}_{\mathrm{Pi}}=\mathrm{p}_{\mathrm{n}}=32,17 \mathrm{MPa}$,

- rotational speed $\left.n_{P}\right|_{p_{n}}=24,73 \mathrm{rev} / \mathrm{s}$,

- increase of torque of mechanical losses

$$
\Delta \mathrm{M}_{\mathrm{Pm} \mid \mathrm{p}_{\mathrm{n}}}=0,533 \mathrm{Nm}
$$

Power of volumetric losses due to leakage in the working chambers:

$$
\Delta \mathrm{P}_{\mathrm{Pvl} \mid \mathrm{p}_{\mathrm{n}}}=\mathrm{q}_{\mathrm{Pvl} \mid \mathrm{p}_{\mathrm{n}}} \times \mathrm{p}_{\mathrm{n}} \times \mathrm{n}_{\mathrm{P} \mid \mathrm{p}_{\mathrm{n}}}=
$$

$=3,905 \mathrm{~cm}^{3} / \mathrm{rev} \times 32,17 \mathrm{MPa} \times 24,73 \mathrm{rev} / \mathrm{s}=3107 \mathrm{~W}$

Power of mechanical losses in the „working chambers shaft" assembly resulting from increase $\Delta \mathrm{M}_{\mathrm{Pm} \mid \mathrm{p}_{\mathrm{n}}}$ of torque of losses:

$$
\begin{aligned}
& \Delta \mathrm{P}_{\mathrm{Pm} \mid \mathrm{p}_{\mathrm{n}}}=\Delta \mathrm{M}_{\mathrm{Pm} \mid \mathrm{p}_{\mathrm{n}}} \times 2 \Pi \mathrm{n}_{\mathrm{P} \mid \mathrm{p}_{\mathrm{n}}}= \\
= & 0,533 \mathrm{Nm} \times 2 \Pi \times 24,73 \mathrm{rev} / \mathrm{s}=83 \mathrm{~W}
\end{aligned}
$$

Sum of powers of losses:

$$
\Delta \mathrm{P}_{\mathrm{Pvl} \mid \mathrm{p}_{\mathrm{n}}}+\Delta \mathrm{P}_{\mathrm{Pm} \mid \mathrm{p}_{\mathrm{n}}}=3107 \mathrm{~W}+83 \mathrm{~W}=\mathbf{3 1 9 0} \mathbf{W}
$$

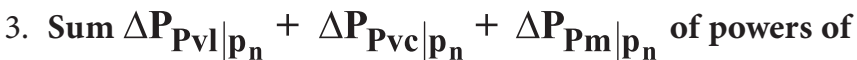
losses determined with taking into account the volumetric losses of oil compression in the chambers at oil aeration coefficient $\varepsilon=0,0135$ (at compressibility coefficient $\mathbf{k}_{\mathbf{l c}\left(\mathbf{p}_{\mathbf{n}}\right)}$ )

Data from pump investigations:

- $\quad$ capacity $\mathrm{q}_{\mathrm{P} \mid \mathrm{p}_{\mathrm{n}}}=55,009 \mathrm{~cm}^{3} / \mathrm{rev}$,

- theoretical capacity $\mathrm{q}_{\mathrm{Pt}}=59,668 \mathrm{~cm}^{3} / \mathrm{rev}$,

- volumetric losses due to compression $\mathrm{q}_{\mathrm{Pvc} \mid \mathrm{p}_{\mathrm{n}}}=2,026 \mathrm{~cm}^{3} / \mathrm{rev}$,

- volumetric losses due to leakage $\mathrm{q}_{\mathrm{Pvl}} \mathrm{p}_{\mathrm{n}}=2,633 \mathrm{~cm}^{3} / \mathrm{rev}$,

- indicated increase of pressure $\Delta \mathrm{p}_{\mathrm{P}_{\mathrm{i}}}=\mathrm{p}_{\mathrm{n}}=32,17 \mathrm{MPa}$,

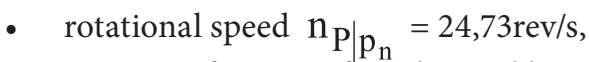

- increase of torque of mechanical losses

$$
\Delta \mathrm{M}_{\mathrm{Pm} \mid \mathrm{p}_{\mathrm{n}}}=1,026 \mathrm{Nm}
$$

Power of volumetric losses of oil compression in the working chambers determined by a simplified formula:

$$
\begin{gathered}
\Delta \mathrm{P}_{\mathrm{Pvc} \mid \mathrm{p}_{\mathrm{n}}}=\frac{\mathrm{q}_{\mathrm{Pvc} \mid \mathrm{p}_{\mathrm{n}}} \times \mathrm{p}_{\mathrm{n}}}{2} \times \mathrm{n}_{\mathrm{P} \mid \mathrm{p}_{\mathrm{n}}}= \\
=\frac{2,026 \mathrm{~cm}^{3} / \mathrm{obr} \times 32,17 \mathrm{MPa}}{2} \times 24,73 \mathrm{obr} / \mathrm{s}=806 \mathrm{~W}
\end{gathered}
$$

Power of volumetric losses due to leakage in the working chambers:

$$
\Delta \mathrm{P}_{\mathrm{Pvl} \mid \mathrm{p}_{\mathrm{n}}}=\mathrm{q}_{\mathrm{Pvl} \mid \mathrm{p}_{\mathrm{n}}} \times \mathrm{p}_{\mathrm{n}} \times \mathrm{n}_{\mathrm{P}}=
$$

$=2,633 \mathrm{~cm}^{3} / \mathrm{obr} \times 32,17 \mathrm{MPa} \times 24,73 \mathrm{obr} / \mathrm{s}=2095 \mathrm{~W}$

Power of mechanical losses in the „working chambers shaft" assembly resulting from increase $\Delta \mathrm{M}_{\mathrm{Pm}} \mid \mathrm{p}_{\mathrm{n}}$ of torque of losses:

$$
\begin{gathered}
\Delta \mathrm{P}_{\mathrm{Pm} \mid \mathrm{p}_{\mathrm{n}}}=\Delta \mathrm{M}_{\mathrm{Pm} \mid \mathrm{p}_{\mathrm{n}}} \times 2 \Pi \mathrm{n}_{\mathrm{P}}= \\
=1,026 \mathrm{Nm} \times 2 \Pi \times 24,73 \mathrm{obr} / \mathrm{s}=159 \mathrm{~W}
\end{gathered}
$$

Sum of powers of losses:

$$
\begin{gathered}
\Delta \mathrm{P}_{\mathrm{Pvc} \mid \mathrm{p}_{\mathrm{n}}}+\Delta \mathrm{P}_{\mathrm{Pvl} \mid \mathrm{p}_{\mathrm{n}}}+\Delta \mathrm{P}_{\mathrm{Pm} \mid \mathrm{p}_{\mathrm{n}}}= \\
=806 \mathrm{~W}+2095 \mathrm{~W}+159 \mathrm{~W}=\mathbf{3 0 6 0 W}
\end{gathered}
$$

Sum 3218W of powers of losses - volumetric losses $\Delta \mathrm{P}_{\mathrm{Pvl} \mid \mathrm{p}_{\mathrm{n}}}$ and $\Delta \mathrm{P}_{\mathrm{Pvc} \mid \mathrm{p}_{\mathrm{n}}}$ in the working chambers and 
mechanical losses $\Delta \mathrm{P}_{\mathrm{Pm} \mid \mathrm{p}_{\mathrm{n}}}$ in the „working chambers - shaft” assembly, the losses resulting from increase $\Delta \mathrm{p}_{\mathrm{Pi}}=\mathrm{p}_{\mathrm{n}}$ of pressure in the working chambers, described by formula (15), is a result of balance of pump useful power $\mathrm{P}_{\mathrm{Pu}} \mid \mathrm{p}_{\mathrm{n}}$, power $\mathrm{P}_{\mathrm{Pc}} \mid \mathrm{p}_{\mathrm{n}}$ consumed by the pump as well as power $\Delta \mathrm{P}_{\mathrm{Pp}}$ of pressure losses in the channels and power $\Delta \mathrm{P}_{\mathrm{Pm}} \mid \Delta \mathrm{p}_{\mathrm{Pi}}=0$ of mechanical losses in the „working chambers - shaft” assembly of no-load pump.

\section{This balance bears the least errors.}

Sum 3190W of powers of losses - volumetric losses $\Delta \mathrm{P}_{\mathrm{Pvl}} \mid \mathrm{p}_{\mathrm{n}}$ and mechanical losses $\Delta \mathrm{P}_{\mathrm{Pm}} \mid \mathrm{p}_{\mathrm{n}}$, determined without taking into account the volumetric losses of oil compression in the chambers, results from the accuracy of evaluation of capacity $\mathrm{q}_{\mathrm{P}} \mid \mathrm{p}_{\mathrm{n}}$ per one shaft revolution and theoretical capacity $\mathrm{q}_{\mathrm{pt}}$, i.e.

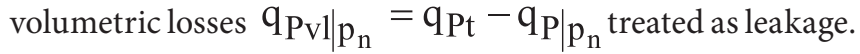

The sum $3190 \mathrm{~W}$ of power of losses is a value of approximately 0,991 of the sum $3218 \mathrm{~W}$ of losses, which confirms the great accuracy of measurements and careful processing of the results.

However, not taking into account the oil aeration and oil compressibility (and also not determining the corresponding theoretical capacity $\mathrm{q}_{\mathrm{Pt}}$ per one shaft revolution) makes the evaluation of volumetric losses $\mathbf{q}_{\mathrm{Pvl}} \mid \mathbf{p}_{\mathbf{n}}$ due to leakage in the

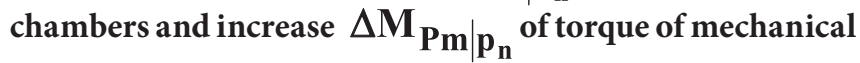
losses in the „working chambers - shaft” assembly deformed. It makes a proper evaluation of the pump design solution, as a source of volumetric and mechanical losses, impossible.

Sum 3060W of power of losses $\Delta \mathrm{P}_{\mathrm{Pvl} \mid \mathrm{p}_{\mathrm{n}}}+\Delta \mathrm{P}_{\mathrm{Pvc} \mid \mathrm{p}_{\mathrm{n}}}+$ $\Delta \mathrm{P}_{\mathrm{Pm} \mid \mathrm{p}_{\mathrm{n}}}$ determined with taking the volumetric losses of oil compression in the working chambers into account, at the oil aeration coefficient $\varepsilon=0,0135$ (oil compressibility coefficient $\left.\mathrm{k}_{1 \mathrm{c}} \mid \mathrm{p}_{\mathrm{n}}=0,034\right)$ by means of the proposed method [10,11], with simplified formula $\Delta \mathrm{P}_{\mathrm{Pvc} \mid \mathrm{p}_{\mathrm{n}}}=\frac{\mathrm{q}_{\mathrm{Pvc} \mid \mathrm{p}_{\mathrm{n}}} \times \mathrm{p}_{\mathrm{n}}}{2} \times \mathrm{n}_{\mathrm{P} \mid \mathrm{p}_{\mathrm{n}}}$ determining power of volumetric losses of oil compression in the working chambers is a value of approximately 0,991 of the sum $3218 \mathrm{~W}$ of power of losses determined with formula (15).

The difference $3218 \mathrm{~W}-3060 \mathrm{~W}=158 \mathrm{~W}$ is a value of approximately 0,003 of power $\mathrm{P}_{\mathrm{P}_{\mathrm{c}}}=47972 \mathrm{~W}$ consumed on the pump shaft.

An important gain of this method is obtaining the possibility of evaluation of values and proportions of the volumetric losses $\mathbf{q}_{\mathbf{P v c}} \mathbf{p}_{\mathbf{n}}$ of oil compression and $\mathbf{q}_{\mathbf{P v l}} \mid \mathbf{p}_{\mathbf{n}}$ due to leakage of oil in the working chambers as well as correct evaluation of increase $\Delta \mathbf{M}_{\mathrm{Pm}} \mathrm{p}_{\mathrm{n}}$ of torque of mechanical losses in the pump „working chambers - shaft” assembly.

\section{CONCLUSIONS}

1. Objective of the work was comparison of powers of energy losses in a variable capacity displacement pump determined without or with taking into account the power of hydraulic oil compression. Evaluation of power of liquid compression in the pump was made possible by the use of method, proposed by the Author, of determining the degree of liquid aeration in the pump $[10,11]$.

2. In the method of determining the liquid aeration in the pump and of power of volumetric losses of liquid compression a simplified formula $\left(\mathrm{q}_{\mathrm{p}_{\mathrm{vc}}} \times \Delta \mathrm{p}_{\mathrm{pi}_{\mathrm{i}}}\right) / 2$ was used describing the field of indicated work of volumetric losses $\mathrm{q}_{\mathrm{pvc}}$ of liquid compression during one shaft revolution at indicated increase $\Delta \mathrm{p}_{\mathrm{P}_{\mathrm{i}}}$ of pressure in the chambers.

3. Based on the results of investigations of a HYDROMATIK A7V.58.1.R.P.F.00 pump [8 - 15] a sum of powers of volumetric losses $\Delta \mathrm{P}_{\mathrm{Pvl}} \mid \mathrm{p}_{\mathrm{n}}$ due to leakage and $\Delta \mathrm{P}_{\mathrm{Pvc}} \mathrm{p}_{\mathrm{n}}$ of compression as well as

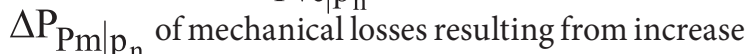
$\Delta \mathrm{p}_{\mathrm{Pi}}=\mathrm{p}_{\mathrm{n}}$ of indicated pressure in the pump working chambers was compared:

- $\quad$ as a difference between power $\mathrm{P}_{\mathrm{Pc}} \mid \mathrm{p}_{\mathrm{n}}$ consumed on the shaft and the sum of useful power $\mathrm{P}_{\mathrm{Pu}} \mid \mathrm{p}_{\mathrm{n}}$, power $\Delta \mathrm{P}_{\mathrm{Pp}}$ of pressure losses in the channels and power $\Delta \mathrm{P}_{\mathrm{Pm} \mid \Delta \mathrm{p}_{\mathrm{Pi}}=0}$ of mechanical losses in no-load $\operatorname{pump}\left(\right.$ at $\left.\Delta \mathrm{p}_{\mathrm{Pi}}=0\right)$,

- $\quad$ as a sum of losses evaluated with the proposed method $[10,11]$ of determining the degree of liquid aeration in the pump:

- without taking into account of volumetric losses $\mathrm{q}_{\mathrm{pvc}}$ of oil compression in the chambers,

- with taking into account the volumetric losses $\mathrm{q}_{\mathrm{pvc}}$ of oil compression.

\section{BIBLIOGRAPHY}

1. Paszota Z.: Effect of the working liquid compressibility on the picture of volumetric and mechanical losses in a high pressuredisplacement pumpusedinahydrostatic drive. Part IEnergylosses in a drive system, volumetriclosses in a pump //International Scientific-Technical Conference Hydraulics and Pneumatics, Wrocław, 16 - 18 maja 2012 / Ośrodek Doskonalenia Kadr SIMP - Wrocław : ODK SIMP we Wrocławiu, 2012

2. Paszota Z.: Effect of the working liquid compressibility on the picture of volumetric and mechanical losses in a high pressure displacement pump used in a hydrostatic drive. Part II Mechanical losses in a pump //International Scientific-Technical Conference Hydraulics and 
Pneumatics, Wrocław, 16 - 18 maja 2012 / Ośrodek Doskonalenia Kadr SIMP - Wrocław: ODK SIMP we Wrocławiu, 2012

3. Paszota Z.: Effect of the working liquid compressibility on the picture of volumetric and mechanical losses in a high pressure displacement pump used in a hydrostatic drive. Part I Energy losses in a drive system, volumetric losses in a pump// Polish Maritime Research, 2/2012, Vol. 19

4. [4] Paszota Z.: Effect of the working liquid compressibility on the picture of volumetric and mechanical losses in a high pressure displacement pump used in a hydrostatic drive. Part II Mechanical losses in a pump // Polish Maritime Research, 3/2012, Vol.19

5. Paszota Z.: Theoretical and mathematical models of the torque of mechanical losses in the pump used in a hydrostatic drive (in Polish). Chapter in the monograph: „Research, design, production and operation of hydraulic systems" (in Polish) Adam Klich, Antoni Kozieł and Edward Palczak editors. „Cylinder” Library. „Komag” Mining Mechanisation Centre, Gliwice, 2011

6. Paszota Z.: Theoretical and mathematical models of the torque of mechanical losses in the pump used in a hydrostatic drive (in Polish). „Napędy i sterowanie”, scientific monthly, 10/2011

7. Paszota Z:: Theoretical models of the torque of mechanical losses in the pump used in a hydrostatic drive Polish Maritime Research, 4 / 2011, Vol. 18

8. Koralewski J.: Effect of the liquid viscosity on the energy characteristics of variable capacity piston pump (in Polish). Doctor dissertation (continued). Gdańsk University of Technology, Faculty of Ocean Engineering and Ship Technology

9. Koralewski J.: Effect of oil viscosity and compressibility on determination of volumetric losses in a variable capacity piston pump (in Polish). Paper submitted to the „Cylinder” 2013 Conference. Centrum Mechanizacji Górnictwa „Komag”, Gliwice, 2013

10. Paszota Z.: Method of determining the degree of liquid aeration in a variable capacity displacement pump Polish Maritime Research, 3 / 2013, Vol. 20

11. Paszota Z.: Method of determining the degree of liquid aeration in a variable capacity displacement pump (in Polish). „Napędy i sterowanie”, scientific monthly, 11/2013

12. Koralewski J.: Influence of viscosity and compressibility of aerated oil on determination of volumetric losses in a variable capacity piston pump (in Polish). „Napędy i sterowanie", scientific monthly, 11/2013
13. Koralewski J.: Influence of viscosity and compressibility of aerated oil on determination of volumetric losses in a variable capacity piston pump Polish Maritime Research, 4 / 2013, Vol. 20

14. Paszota Z.: Mathematical model defining volumetric losses of hydraulic oil compression in a variable capacity displacement pump (in Polish) „Napędy i sterowanie”, scientific monthly, 10/2014

15. Paszota Z.: Mathematical model defining volumetric losses of hydraulic oil compression in a variable capacity displacement pump Paper submitted for publication in the "Polish Maritime Research" journal

\section{CONTACT WITH THE AUTHOR}

\author{
Zygmunt Paszota \\ Gdańsk University of Technology \\ 11/12 Narutowicza St. \\ 80 - 233 Gdańsk \\ Poland
}

